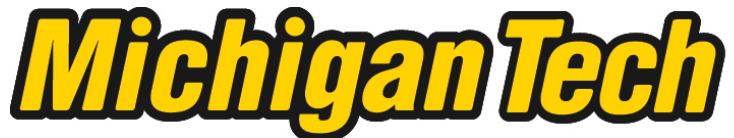 \\ Michigan Technological University Create the Future Digital Commons @ Michigan Tech
}

Dissertations, Master's Theses and Master's Reports - Open

Dissertations, Master's Theses and Master's

Reports

2012

\section{Management impacts on Carex assiniboinensis and Cardamine concatenata on the Ottawa National Forest}

Margaret Fox

Michigan Technological University

Follow this and additional works at: https://digitalcommons.mtu.edu/etds

Part of the Forest Sciences Commons

Copyright 2012 Margaret Fox

\section{Recommended Citation}

Fox, Margaret, "Management impacts on Carex assiniboinensis and Cardamine concatenata on the Ottawa National Forest", Master's report, Michigan Technological University, 2012.

https://doi.org/10.37099/mtu.dc.etds/136

Follow this and additional works at: https://digitalcommons.mtu.edu/etds

8 Part of the Forest Sciences Commons 


\title{
MANAGEMENT IMPACTS ON CAREX ASSINIBOINENSIS AND CARDAMINE CONCATENATA ON THE OTTAWA NATIONAL FOREST
}

\author{
By \\ Margaret M. Fox
}

\begin{abstract}
A REPORT
Submitted in partial fulfillment of the requirements for the degree of MASTER OF SCIENCE

(Forestry)
\end{abstract}

MICHIGAN TECHNOLOGICAL UNIVERSITY

2012

(C) 2012 Margaret M. Fox 
This report, "Management Impacts on Carex assiniboinensis and Cardamine concatenata on the Ottawa National Forest," is hereby approved in partial fulfillment of the requirements for the Degree of MASTER OF SCIENCE IN FORESTRY.

School of Forest Resources and Environmental Science

Signatures:

Report Advisor

Dr. Blair Orr

Dean

Dr. Terry L. Sharik

Date 


\section{Table of Contents}

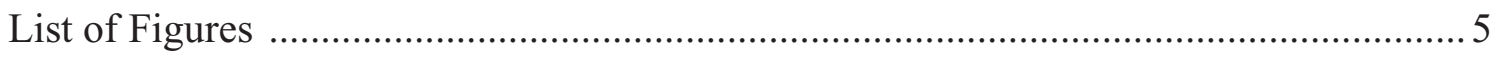

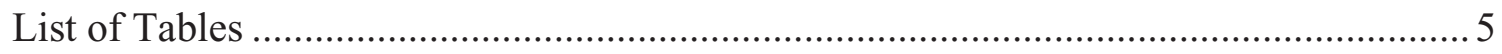

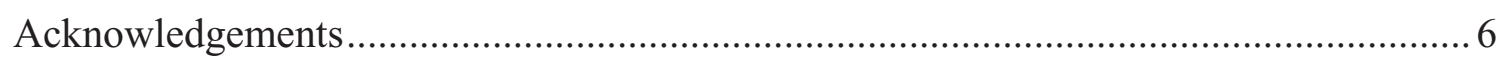

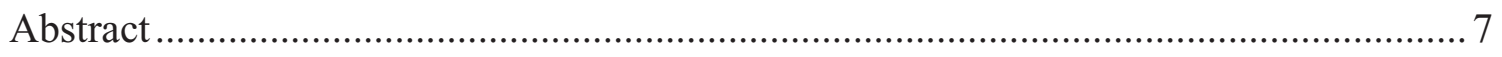

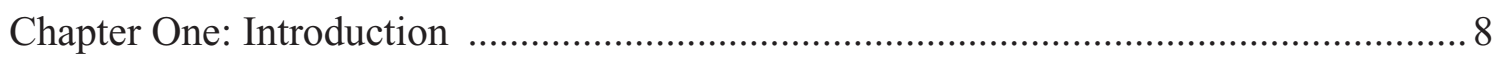

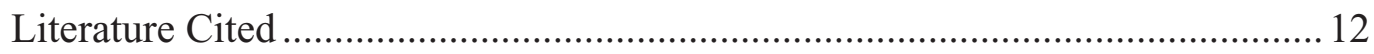

Chapter Two: Effect of Selection Logging on Carex assiniboinensis W. Boott in a

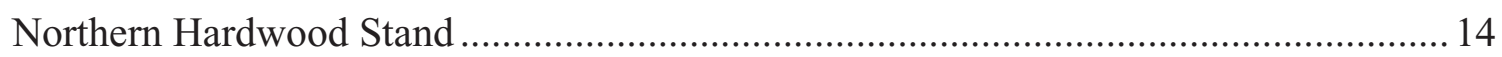

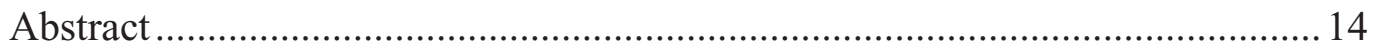

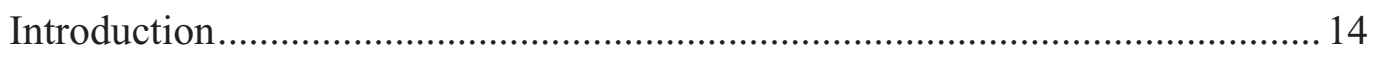

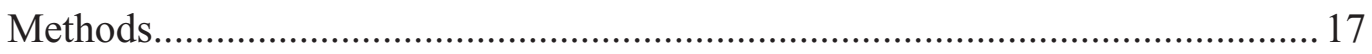

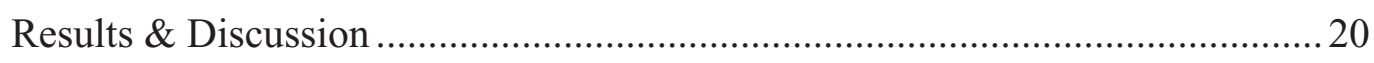

Literature Cited...................................................23

Chapter Three: Suitability of Cardamine concatenata (Michx.) Sw. as a

Management Indicator Species on the Ottawa National Forest........................ 27

Abstract..............................................................27

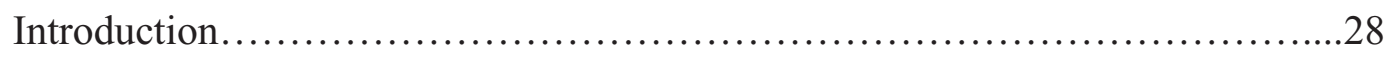

Indicator Species in Forest Management ............................................. 28

Herbaceous Species as Ecosystem Health Indicators of Forest Management

The Forest Service MIS System ..................................................... 35 
C. concatenata as an indicator of northern hardwood forest management

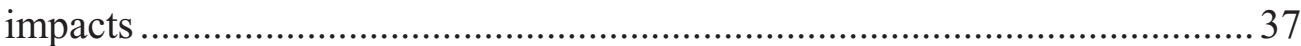

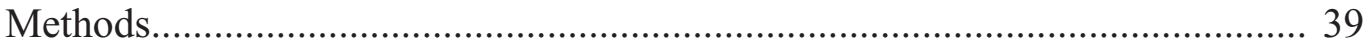

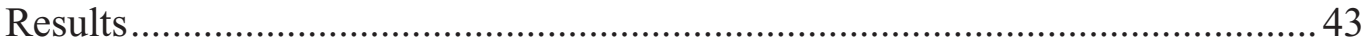

Effects of harvest on site conditions ................................................... 43

Suitability of C. concatenata as a MIS ................................................... 45

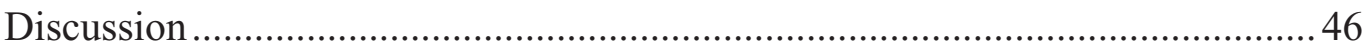

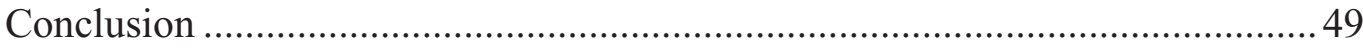

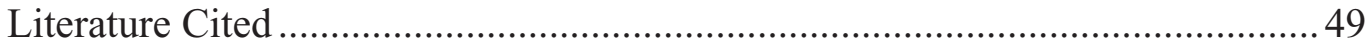

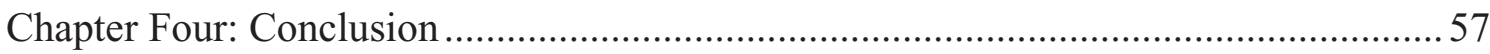

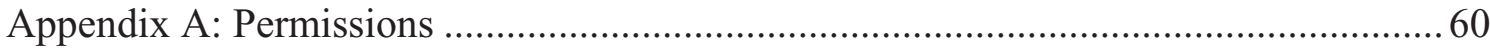




\section{List of Figures}

Figure 2.1. Carex assiniboinensis. Photo taken by Emmet J. Judziewicz ..................... 16

Figure 2.2. Dense C. assiniboinensis cover from survey site. Photo taken by Ian

Shackleford 18

Figure 2.3. Mean number of sedge plants over the seven years of monitoring. $n=16$ for years 1 through $6 . n=10$ for year 7 .

Figure 2.4. Linear regression of sedge presence as a function of time. $\mathrm{x}=$ year of study

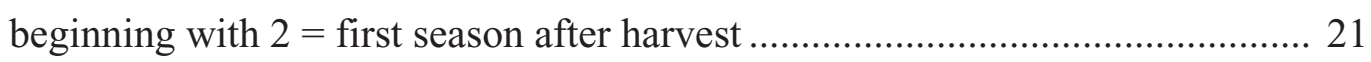

Figure 3.1. Flowering C. concatenata. Photo taken by Kyle Steele ............................. 37

Figure 3.2. C. concatenata during senescence taken while surveying on the ONF. Photo taken by Peggy Fox. 39

Figure 3.3. Location of monitored stands across the Ottawa National Forest in Michigan's Upper Peninsula. Spatial data from USDA Ottawa National Forest

Figure 3.4. Abundance of C. concatenata in treated and non-treated stands. $n=131 \ldots . .42$

\section{List of Tables}

Table 2.1. Mean and standard deviation values for sedge presence on all transects. Year 1 is the year before harvest. $n=16$ for years 1 through $6 . n=10$ for year $7 . .19$

Table 3.1. Relationship between $C$. concatenata and management activity type. $n=66$, $\mathrm{df}=6$ 


\section{Acknowledgements}

Thank you to my advisor, Blair Orr, who provided his support, wisdom, and perspective and served as one of few dependable constants through an ever-challenging and -changing four years of study and Peace Corps service. With his help and encouragement, I have greatly increased my depth of knowledge and awareness of my capabilities.

I am indebted to the generosity of Susan Trull, botanist on the Ottawa National Forest, for not only sharing her data, but also her time and knowledge. She has assisted me in enriching my understanding of management dynamics on the Ottawa and in improving the content and accuracy of this report.

Thank you to my committee members, Sandra Boschetto-Sandoval and Thomas Pypker for your valuable guidance and feedback.

Even though the research I conducted during my Peace Corps service was not utilized in this report, I still owe my appreciation to all who lent a helping hand in Ecuador: Katy Hintzen, Jessica Haswell, Cesario Villalta, Inés Brito, Eduardo Santi, Lilia Barzallo, Dimas Arévalo Dona Blanca López.

Finally, thank you to my family for their guidance and unconditional support, which have shaped my choices, contributed to my successes, and provided me with resolve to continue forward in the face of challenges. Through this unexpected research project on the Ottawa National Forest, I have taken joy in contributing to the richness of the forests so near to Lone Pine Lake and so dear to our family. 


\begin{abstract}
Monitoring of herbaceous plants on the Ottawa National Forest (ONF) is used to understand the impact of forest management on understory composition and site conditions. In their planning, national forests are required to take into account management impacts on diversity and ecosystem health. The effect of management on understory species is dependent on various factors, including the intensity of disturbance and the biology of the plant. In the first study in this report, a population of Carex assiniboinensis, a Michigan state threatened species, was monitored for seven seasons including before logging commenced, in order to determine the sedge's response to a single-tree selection harvest. Analyses provided insights for management of $C$.

assiniboinensis at the stand level over the short-term. In the second study in this report, the use of the cutleaf toothwort (Cardamine concatenata) as a Management Indicator Species on the ONF was reviewed. Data were analyzed to determine the suitability of using $C$. concatenata to monitor impacts of forest management on site conditions. The various factors that affect understory species population dynamics illuminated the challenges of using indicator species to monitor site conditions. Insights from the study provide a greater understanding of management impacts on understory species across the Ottawa National Forest.
\end{abstract}




\section{Chapter One}

\section{Introduction}

The following two studies were conducted on the Ottawa National Forest (ONF). The ONF is located in the western part of the Upper Peninsula of Michigan, with the Forest Supervisor's office based in Ironwood, Michigan. The ONF was established as a national forest in 1931. At that time, the forest encompassed 253,551 acres. Today the total area of the forest is almost one million acres. Roughly one-half of the land area is covered by northern hardwoods; twenty-two percent by aspen-paper birch; $18 \%$ by shortlived conifers including jack pine, balsam fir, tamarack, and northern white cedar; and $10 \%$ by long-lived conifers, which include red and white pine, hemlock, and white spruce (U.S.D.A. Forest Service 2006).

National forests are charged with managing for multiple uses. Each forest must balance the objectives of managing forest resources for productivity with conserving “ecological integrity" and "species diversity" (36 C.F.R. § 219 2012). Under the “biodiversity mandate" within the 1976 National Forest Management Act (NFMA), all national forests must "provide for diversity of plant and animal communities based on the suitability and capability of the specific land area in order to meet overall multiple-use objectives" (16 U.S.C. $\S 1600(\mathrm{~g})(3)(B))$. This mandate requires that forest planning take into account potential impacts of harvesting on site conditions and species composition. Upholding this mandate proves challenging for Forest Service staff given the complexity of resource dependencies and reactions to management of each plant and animal species.

Within forest ecosystems, understory species play an important functional role as well as provide insights into ecosystem health (Burke et al 2008). Understory plants 
provide habitat and forage for forest-dwelling animals. In their position on the forest floor, they have micro-level impacts on soil and hydrological processes and are also more sensitive to such processes (Reader and Bricker 1992). They play a role in regulating these processes by, for example, providing ground cover and preventing erosion in canopy openings. With the loss of rare species, the diversity and the resilience of ecosystems are diminished (Lyons and Schwartz 2001). They are useful as indicators of site conditions due to their sensitivity to changes in moisture, light, and soil structure (Burke et al 2008). The abundance of a species at a site is informative of various stand characteristics, such as resource availability, habitat suitability, degree of impact of and recovery from recent disturbance, and stage of succession (Metzger and Shultz 1984). Monitoring of understory species can therefore be used to track population trends of surveyed species and to correlate these trends to site conditions (Brosofske et al. 2001).

In this report, monitoring data is used to assess the impact of forest management on understory species in northern hardwood stands. Changes to understory composition are determined by various factors, including the degree of disturbance and the unique biology of each species. Species dependent on higher-light environments typically increase in abundance following harvest of overstory trees. Where harvest is intensive, such as under group selection or clearcutting, competition from invasive species can negatively affect native species (Meier et al. 1995; Zenner and Berger 2008). As the canopy closes, understory species composition shifts again as the result of lower light availability (Barnes et al. 1998). As time from harvest increases, species composition and abundance will be expected to change and reflect the stage of stand succession. 
In the stands monitored in this report, management activities were limited to those that are meant to mimic natural disturbances. Stands were managed using single-tree selection of overstory trees and thinning in the understory. These methods are known to be less destructive to understory species composition than group selection and clearcutting (Barnes et al. 1998; Zenner et al. 2006). Harvesting was conducted during winter months in order to reduce disturbance to the forest floor.

In the first study in this report, one population of Carex assiniboinensis covering approximately five to ten acres was monitored to assess its response to a single-tree selection harvest. C. assiniboinensis is a Michigan state threatened plant and only a few populations exist in the state. Factors contributing to its rare status are unknown and the impacts of management on the sedge are poorly understood. The area around the sedge population was not protected because it was identified only after it was too late to amend the terms of the contract. The population was monitored in the season before and for five years following harvest. Results from the analysis are presented in Chapter Two.

In the second study, monitoring of a Management Indicator Species (MIS) is used to assess impacts of forest management on site conditions. On the ONF, the cutleaf toothwort (Cardamine concatenata), a spring ephemeral, is one of four MIS. Spring ephemerals are considered particularly important as regulators and indicators of ecosystem processes. In northern forests, their emergence following snowmelt occurs at a time when biological activity in the forest is low. The timing of nutrient uptake in a few species has been shown to function as a vernal dam in preventing nutrient loss from forested sites (Blank et al. 1980). Spring ephemerals are believed to be useful as indicator species for monitoring of changes that result from disturbance because of their 
sensitivity to changes in site conditions, irrespective of resource availability as affected by overstory activity and understory competition. They also have low dispersal rates, which limits their recolonization of sites after disturbance. In 131 stands across the ONF abundance of the indicator species, the cutleaf toothwort (Cardamine concatenata), as well as abundance of three other spring ephemeral plants (Cardamine diphylla, Claytonia caroliniana, and Allium tricoccum) were surveyed along with other relevant site characteristics. In Chapter Three, monitoring data is analyzed for insights into the impact of forest management on C. concatenata and the suitability of that species as a MIS.

Specific and broad insights can be derived from the two studies. Monitoring data from each of the five plants (C. assiniboinensis, C. concatenata, C. diphylla, $C$. caroliniana, and A. tricoccum) is used to garner a more precise understanding of the relationship of each plant to harvesting and to other external factors potentially affecting their populations. The second chapter provides new insights into management of Carex assiniboinensis and the third chapter highlights the challenges in monitoring forest management impacts under the MIS system. The species studied in both cases are considered sensitive to disturbance and monitoring of their populations are therefore important for understanding ecosystem health. Short- and long-term impacts on understory species were observed, both at the stand level and across the forest. For Forest Service staff charged with conserving plant and animal habitats across the vast and diverse ONF, the insights from this study can be used to inform future management. 


\section{Literature Cited}

Barnes, B. V., D. R. Zak, S. R. Denton, and S. H. Spurr. 1998. Forest Ecology: Fourth Edition. New York: John Wiley \& Sons, Inc.

Blank, J. L., R. K. Olson, and P. M. Vutousek. 1980. Nutrient uptake by a diverse spring ephemeral community. Oecologia 47:96-98.

Brosofske, K.D., J. Chen, T.R. Crow. 2001. Understory vegetation and site factors: Implications for a managed Wisconsin landscape. Forest Ecol. Manag. 146:7587.

Burke, D.M., K.A. Elliot, S.B. Holmes, and D. Bradley. 2008. The effects of partial harvest on the understory vegetation of southern Ontario woodlands. Forest Ecol. Manag. 225:2204-2214.

Lyons, K. G. and M. W. Schwartz. 2001. Rare species loss alters ecosystem function invasion resistance. Ecology Letters 4:358-365.

Meier, A. J., S. P. Bratton and D. C. Duffy. 1995. Possible ecological mechanisms for loss of vernal herb diversity in logged eastern deciduous forests. Ecol. Appl. 5: 935-946.

Metzger, F, and J. Schultz. 1984. Understory response to 50 years of management of a northern hardwood forest in Upper Michigan. Am. Midl. Nat. 112:209-223.

Reader, R.J. and B.D. Bricker. 1992. Value of selection cut deciduous forest for understory herb conservation: an experimental assessment. Forest Ecol. Manag. $51: 317-327$

National Forest Management Act. 1976. 16 U.S.C. $§ 1600(g)(3)(B)$. 
National Forest System Land and Resource Management Planning rule. 2012. 36 C.F.R. $\S 219$.

U.S. Department of Agriculture, Forest Service. 2006. Ottawa National Forest Final Environmental Impact Statement, Forest Plan. Ironwood, MI: Ottawa National Forest. 3-39-3-50.

Zenner, E. K. and A. L. Berger. 2008. Influence of skidder traffic and canopy removal intensities on the ground flora in a clearcut-with-reserves northern hardwood stand in Minnesota, USA. Forest Ecol. Manag. 256:1785-1794.

Zenner, E. K., J. M. Kabrick, R. G. Jensen, J. E. Peck, and J. K. Grabner. 2006. Responses of ground flora to a gradient of harvest intensity in the Missouri Ozarks. Forest Ecol. Manag. 222:326-334. 


\title{
Chapter Two
}

\section{Effect of Selection Logging on Carex Assiniboinensis W. Boott in a Northern Hardwood Stand}

\begin{abstract}
A population of Carex assiniboinensis W. Boott (assiniboia sedge) was monitored during the season before and for six years following a winter selection harvest in a sugar maple-eastern hemlock stand on the Ottawa National Forest in the Upper Peninsula of Michigan. A mean increase in sedge presence of $136 \%$ was observed over the seven years of monitoring. General linear regression of sedge presence data indicated a significantly positive trend over the natural log-transformation of time. Results of the study indicate that winter selection logging in northern hardwood forests may benefit populations of this threatened species over the short term.
\end{abstract}

Keywords: Carex assiniboinensis, assiniboia sedge, selection logging, threatened species, Michigan, Great Lakes Forests

\section{Introduction}

A population of Carex assiniboinensis W. Boott (assiniboia sedge) was monitored during the season before and for six years following a winter selection harvest in a sugar maple-eastern hemlock stand on the Ottawa National Forest (ONF) in the Upper Peninsula of Michigan. Considering its status as a state threatened species, a 250-foot buffer would have typically been established around the area covered by the species, 
within which logging and other ground-disturbing activity would have been prohibited (e.g. USDA Forest Service 2004). The population, however, was not discovered until after the timber sale contract was awarded. Unable to prevent the harvest from occurring, the Ottawa National Forest Botany Program designed a monitoring program to investigate potential effects of overstory selection logging on C. assiniboinensis. In addition, the timber sale contract was amended to include the following measures to protect the sedge population: (1) delay of harvest activity until snow cover was at least six inches and (2) removal of all harvest-produced slash from the sedge population area.

C. assiniboinensis is a perennial sedge in the Cyperaceae family (Figure 2.1). It is easily identified by its long above-ground vegetative shoots (called stolons) that can extend up to 2 meters in length, at the end of which new plants form (Tolstead 1946; Hipp 2008; USDA NRCS 2012; Voss and Reznicek 2012). The stolons are observable in late-summer, while flowering usually occurs in June and July (Penskar and Higman 1999).

C. assiniboinensis is found on moist sites, in mesic deciduous and mixed forests, floodplains, and river banks. Its native range extends from northern Iowa in the south, southeastern Saskatchewan in the west, and east to parts of southern Ontario and the Upper Peninsula of Michigan (Flora of North America 1993; Penskar and Higman 1999; USDA NRCS 2012). Michigan is the only state in which the plant is listed as threatened, and its conservation status is imperiled (S2) in Michigan, Ontario, and Saskatchewan and vulnerable (S3) in Manitoba and Iowa (NatureServe 2012). According to the University of Wisconsin Herbarium, it has a coefficient of conservatism of nine (on a scale of ten), 
meaning it is believed to have a high affinity for undisturbed sites (Robert W. Freckmann Herbarium).

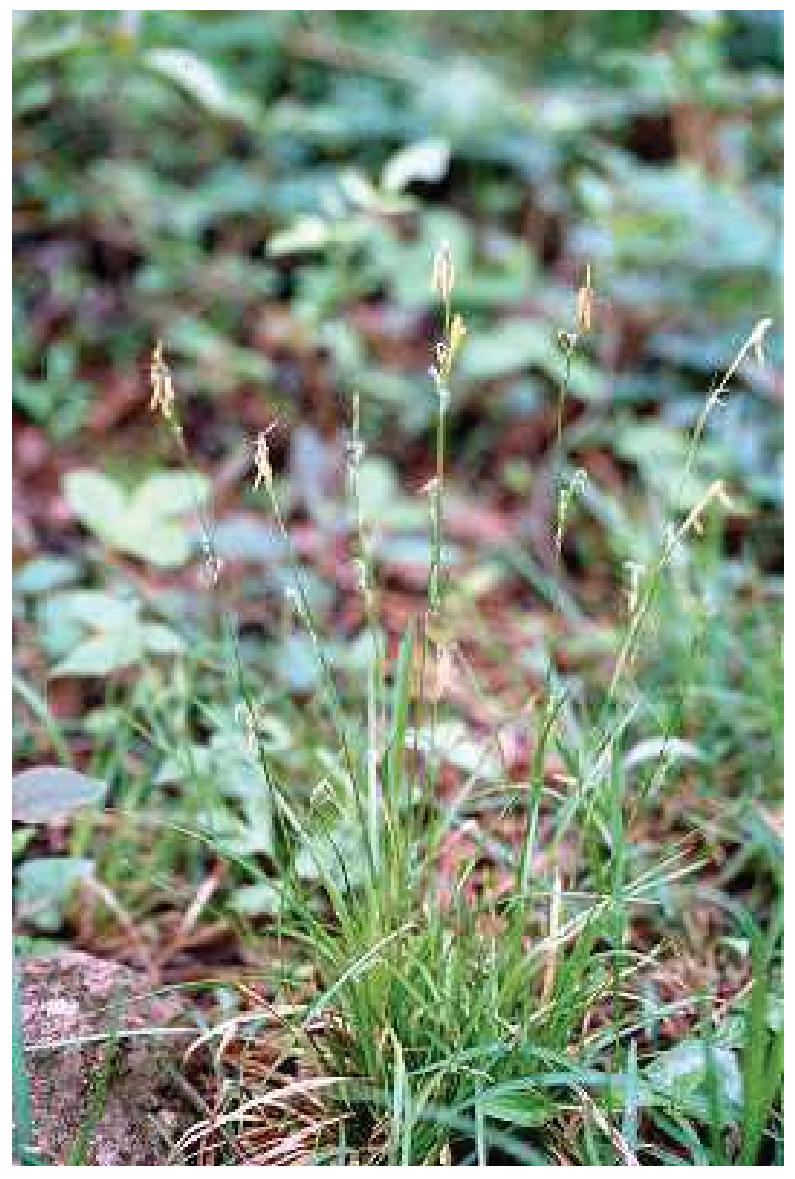

Figure 2.1. C. assiniboinensis (Judziewicz).

Effects of overstory management on C. assiniboinensis populations are poorly understood. Tolstead (1946) hypothesized that stolon growth is encouraged by light, but no research since that time has confirmed whether an increase in light would contribute to population growth. The Michigan Natural Features Inventory recommends that until the effects of timber harvest on C. assiniboinensis populations can be better understood, 
logging should be avoided altogether or at least limited to selection cutting during winter months (Penskar and Higman 1999).

In this study, it was hypothesized that sedge growth could be promoted as the result of increased light penetration following the creation of canopy gaps. This hypothesis was formed based on presence of the sedge on old skid trails in the Ottawa National Forest. It is also supported by studies carried out on sugar maple-dominated forests in the Upper Peninsula of Michigan in which percent cover of understory species (Fredericksen 1998; Scheller and Mladenoff 2002; Wolf et al. 1998), and more specifically sedges (not identified to species) in the Upper Peninsula (Metzger and Shultz 1984) and in bottomland hardwoods in Louisiana (McComb and Noble 1982), were found to increase following selection cutting.

\section{Methods}

The surveyed population of C. assiniboinensis (Figure 2.2) covers a roughly Ushaped area of approximately five to ten acres located in Beechwood Quadrangle in Iron County, MI (T44N R36W S31). The first monitoring was conducted in September of 1999 and was carried out every September through 2005. Harvesting was conducted in the winter of 1999-2000 on the western portion of the U-shaped area and in 2000-2001 on the eastern portion, with a target residual basal area of 85 square feet per acre in both.

Permanent, parallel southeast-northwest running transects were established at randomly spaced distances along the east and west sides of the U-shaped area. The sampling regime used permanent transects in order to (1) be able to monitor changes in the population over time, and (2) allow for the use of a fewer number of sampling points 
than would be required to meet the same level of accuracy in non-permanent transects (Elzinga et al. 1998). Ten transects were established on the west side and six on the east side. From the fixed starting point, sampling along each transect started at a random distance between one and nine meters on the west and one and five meters on the east side. The starting point and subsequent sampling points, which were spaced one meter apart, therefore changed every year. Thirty points were sampled on each transect on the west side and 25 on each transect on the east side. At each point, presence or absence of the sedge was recorded. A sum value for each transect was recorded and then the values from west-side transects were normalized to 25 points.

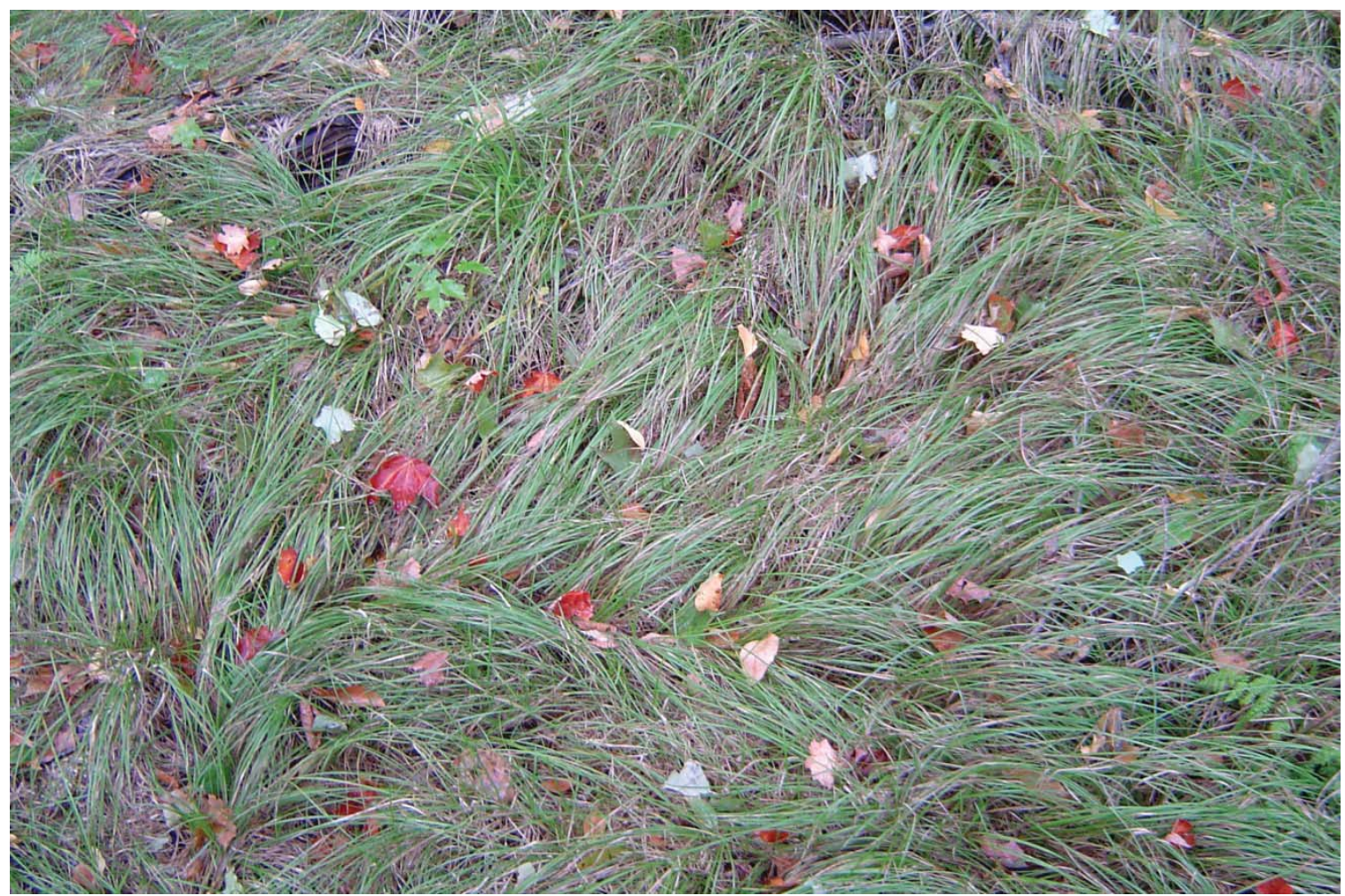

Figure 2.2. Dense C. assiniboinensis cover from survey site. Photo taken by Ian Shackleford. See Appendix A for permission to reproduce this photo. 
Table 2.1. Mean and standard deviation values for sedge presence on all transects. Year 1 is the year before harvest. $\mathrm{n}=16$ for years 1 through $6 . \mathrm{n}=10$ for year 7 .

\begin{tabular}{ccc}
\hline Year & Mean & Standard Error \\
\hline 1 & 8.44 & 1.04 \\
2 & 10.00 & 1.25 \\
3 & 16.44 & 1.37 \\
4 & 17.13 & 1.23 \\
5 & 18.75 & 1.11 \\
6 & 19.19 & 1.02 \\
7 & 19.99 & 1.42 \\
\hline
\end{tabular}

Data were analyzed in SAS software (SAS Institute Inc., Cary N.C.) using PROC GLM for general linear regressions. General linear regressions were used to identify a trend in sedge presence following harvest. The data were analyzed as one data set, with year one as the season before harvest for the west (1999-2000) and the east (2000-2001) sides. For the west transects, monitoring data from the six years following harvest were analyzed, and for the east transects, data from the five years following harvest were analyzed. Year seven only included data from the west transect. Results were declared significant at $\mathrm{p}$ $<0.05$. 


\section{Results \& Discussion}

A mean increase in sedge presence of $136 \%$ was observed over the seven years of monitoring (Figure 2.3). A linear regression equation was used to model the effect of time on sedge presence using the natural log of year of survey as the independent variable and sedge presence as the dependent variable for each individual transect and for the mean value of all transects. In order to analyze the response of the sedge following logging, only the data from the second (2000) through seventh year (2005), for the west side, and the third (2001) through seventh (2005) year for the east side, were used. The regression analysis showed a significant positive trend in mean sedge presence over time $\left(\mathrm{R}^{2}=0.89 ; \mathrm{p}=0.005\right)($ Figure 2.4$)$

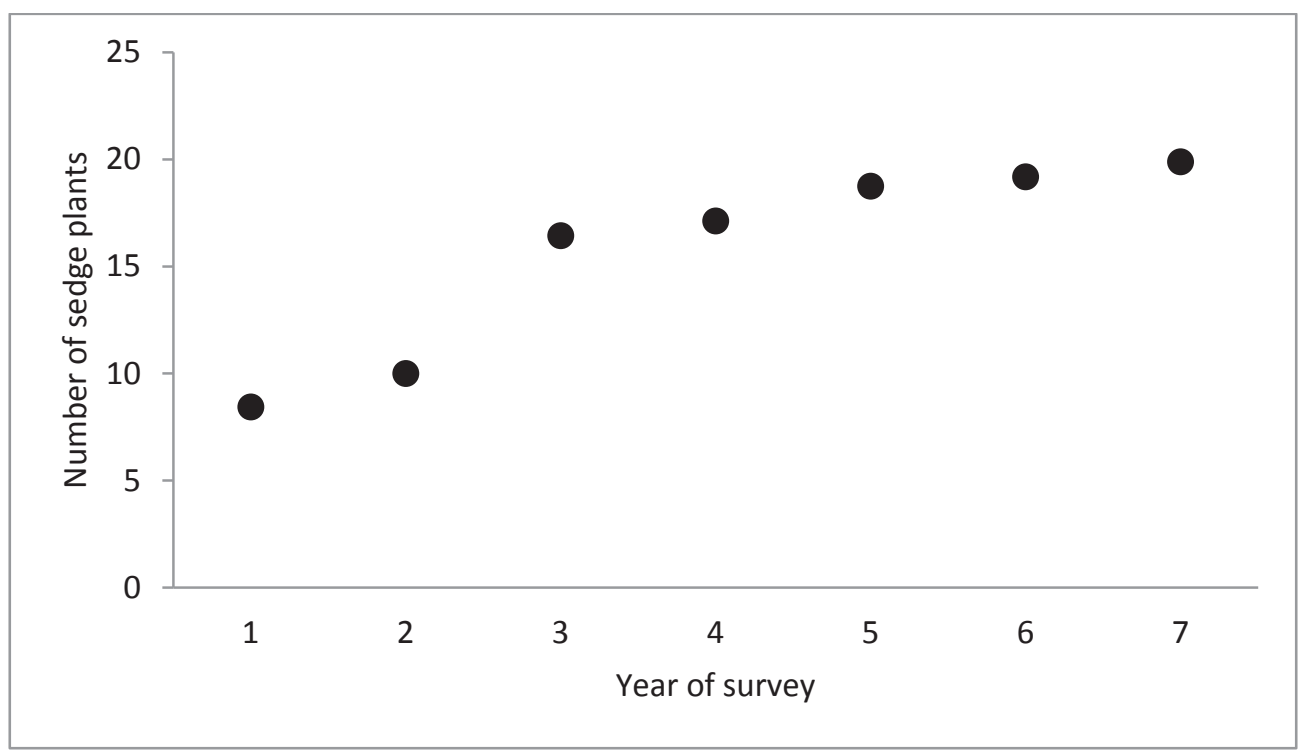

Figure 2.3. Mean number of sedge plants over the seven years of monitoring. $n=16$ for years 1 through $6 . n=10$ for year 7 . 


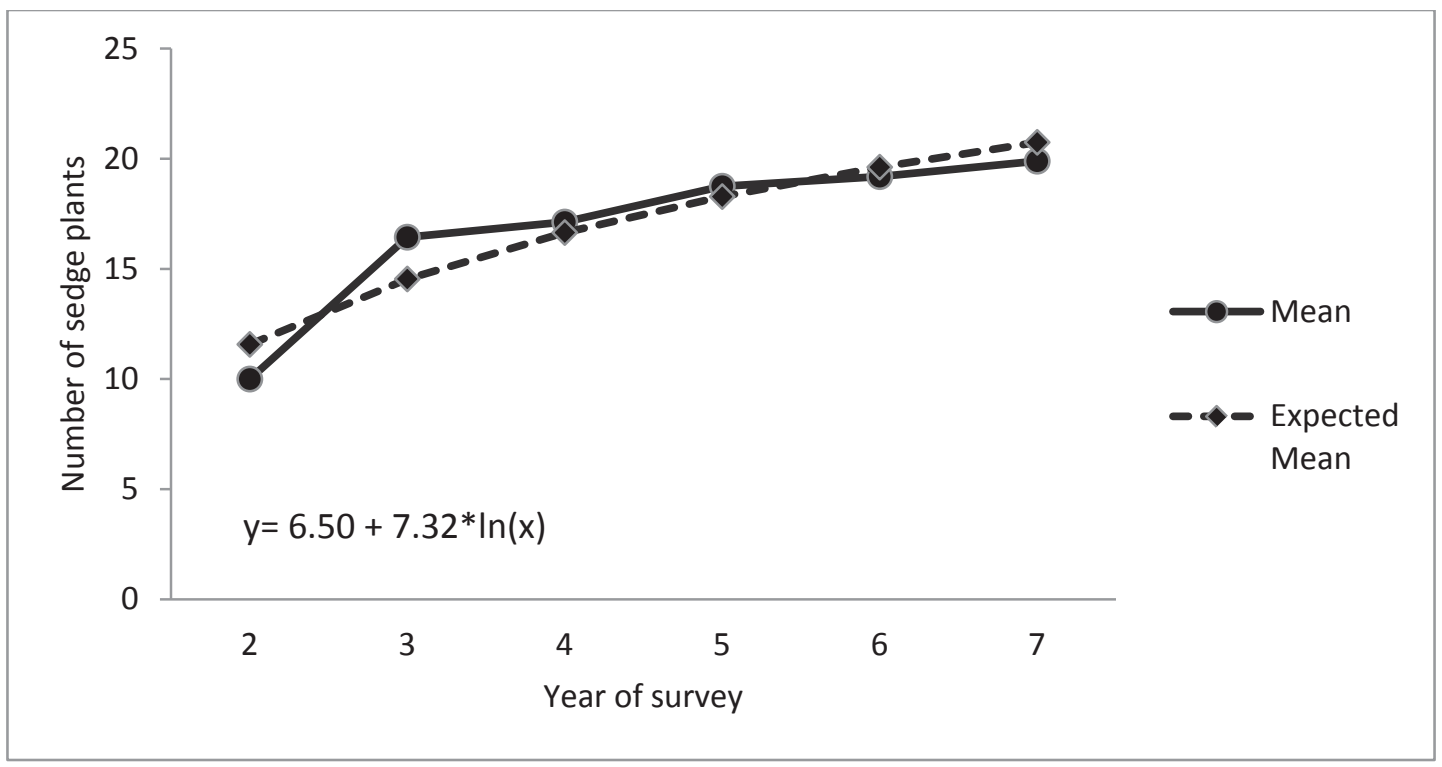

Figure 2.4. Linear regression of sedge presence as a function of time. $\mathrm{x}=$ year of study beginning with 2 = first season after harvest.

Results of the study indicate that winter selection logging in a northern hardwood forest where C. assiniboinensis is present had the effect of increasing sedge population cover over the short-term. This result is consistent with previous research demonstrating that in northern hardwood forests under uneven-aged management, understory species had greater cover and density than in uncut stands. Research conducted on the Ottawa and Nicolet National Forests, in Upper Michigan and Wisconsin respectively, has shown that understory percent cover increased after harvest (Scheller and Mladenoff 2002). In hardwood stands in Pennsylvania, as residual basal area decreased with increasing harvest intensity, percent ground cover also increased (Fredericksen et al. 1998). Sedges, not identified to species, were found to increase in cover following harvests and peak four and five years after logging (Metzger and Schultz 1984). From observations made 19 months after harvest, sedge species were determined to have a greater relative 
importance in cut stands versus uncut stands in bottomland hardwoods in Louisiana (McComb and Noble 1982). Understory species have also been found to be more numerous and have a higher density below natural canopy gaps than on undisturbed sites (Ehrenfeld 1980).

An increase in dominance of C. assiniboinensis in relation to other species was observed in the field, and is consistent with related studies. When comparing undisturbed sites to those with canopy gaps, both naturally occurring and following selection cutting, no difference in species richness or diversity has commonly been observed. (Ehrenfeld 1980; McComb and Noble 1982; Fredericksen 1998; Wolf et al 2008). This trend indicates that the average increase in percent cover of understory species following harvest is often the result of an increase in density and number of plants of species already present on the site, and not because of colonization by new plants. This phenomenon is supported by research where already present species were more dominant in disturbed sites (Ehrenfeld 1980), and where importance of a few species groups, including sedges, increased following harvest (McComb and Noble 1982).

Increased penetration of light to the forest floor was a likely factor in supporting sedge growth. Studies into the effects of canopy gaps on understory vegetation cite the increase in light penetration resulting from the creation of gaps as a causal factor in increased ground cover following selection cutting (McComb and Noble 1982; Reader and Bricker 1992).

Limiting harvest activities to winter months could have also contributed to the positive response of the sedge. Harvesting over exposed ground causes soil disturbance and compaction, which can change microclimates and site suitability for understory 
plants (Brais 2001). Restricting logging to winter months over snowpack or frozen ground results in less impact on understory abundance and percent cover than when logging is conducted during summer months. Species that are more vulnerable to disturbance (coefficient of conservatism $>6$ ) are also less likely to be found on summerlogged sites (Wolf et al. 2008). The high coefficient of conservatism value of 9 attributed to C. assiniboinensis (Robert W. Freckmann Herbarium) indicates that if logging was not restricted to the winter, different results may have been observed in this study.

The results indicate that winter selection logging in hardwood forests can have a positive impact on populations of $C$. assiniboinensis, at least in the short term. Based on this case study, it may not be necessary to exclude selection cutting from an area where C. assiniboinensis, despite its threatened status. Without more research, it is advisable to limit harvest activities to winter months and to remove slash from the sedge population area following harvest.

\section{Literature Cited}

Brais, S. 2001. Persistence of soil compaction and effects on seedling growth in Northwestern Quebec. Soil Sci. Soc. Am. J. 65:1263-1271.

Chen, J., S. C. Saunders, T. R. Crow, R. J. Naiman, K. D. Brosofske, G. D. Mroz, B. L. Brookshire, and J. F. Franklin. 1999. Microclimate in Forest Ecosystem and Landscape Ecology. BioScience 49: 288-297.

Ehrenfeld, J. G. 1980. Understory response to canopy gap of varying size in mature oak forest. Bull. Torrey Bot. Club 107:29-41. 
Elzinga, C. L., D. W. Salzer and J. W. Willoughby. 1998. Measuring and monitoring plant populations. USDI-BLM Technical Reference 1730-1. Denver, CO: USDIBLM.

Flora of North America Editorial Committee. 2002. Flora of North America, North of Mexico. Volume 23: Magnoliophyta: Commelinidae (in part): Cyperaceae. New York: Oxford University Press, 468.

Fredericksen, T. S., B. D. Ross, W. Hoffman, M. L. Morrison, J. Beyea, B. N. Johnson, M.B. Lester, E. Ross. 1998. Short-term understory plant community responses to timber-harvesting intensity on non-industrial private forestlands in Pennsylvania. Forest Ecol. Manag. 116:129-139.

Gehlhausen, S. M., M. W. Shwartz and C. K. Augspurger. 2000. Vegetation and microclimatic edge effects in two mixed-mesophytic forest fragments. Plant Ecol. 147: 21-35.

Heithecker, T. D. and C. B. Halpern. 2007. Edge-related gradients in microclimate in forest aggregates following structural retention harvests in western Washington. Forest Ecol. Manag. 248: 163-173.

Hipp, A. 2008. Field guide to Wisconsin sedges: an introduction to the genus Carex (Cyperaceae). Madison, WI: University of Wisconsin Press, 65.

Judziewicz, E. University of Wisconsin Stevens-Point: Robert W. Freckmann Herbarium, http://wisplants.uwsp.edu/scripts/detail.asp?SpCode=CARASS (accessed July 12, 2012). 
McComb, W. C. and R. E. Noble. 1982. Response of understory vegetation to improvement cutting and physiographic site in two mid-south forest stands. Castanea 47:60-77.

Metzger, F, and J. Schultz. 1984. Understory response to 50 years of management of a northern hardwood forest in Upper Michigan. Am. Midl. Nat. 112:209-223.

NatureServe. 2012. NatureServe Explorer: An online encyclopedia of life (web application). Version 7.1. Arlington, VA: NatureServe. http://www.natureserve.org/explorer (accessed: July 23, 2012 ).

Penskar, M. R. and P. J. Higman. 1999. Special plant abstract for Carex assiniboinensis (Assiniboia sedge). Lansing, MI: Michigan Natural Features Inventory.

Reader, R.J. and B.D. Bricker. 1992. Value of selection cut deciduous forest for understory herb conservation: an experimental assessment. Forest Ecol. Manag. $51: 317-327$

Robert W. Freckmann Herbarium, University of Wisconsin Stevens-Point, http://www.botany.wisc.edu/wisflora/ (accessed May 28, 2012).

Scheller, R. M., and D. J. Mladenoff. 2002. Understory species patterns and diversity in old-growth and managed northern hardwood forests. Ecol Appl. 12:1329-1343.

Tolstead, W. L. 1946. Stolons of Carex assiniboinensis Boott in Iowa. Am. Midl. Nat. 35:797.

USDA, Forest Service. 2004. Camp 7 vegetation management project environmental assessment. Ironwood, MI: Ottawa National Forest, 2-9.

USDA, NRCS PLANTS Database, http://plants.usda.gov (accessed May 14, 2012). 
Voss, E.G. and A.A. Reznicek. 2012. Field manual of Michigan flora. Ann Arbor, MI: University of Michigan Press, 104.

Wolf, A. T. L. Parker, G. Fewless, K. Corio, J. Sundance, R. Howe, H. Gentry. 2008. Impact of summer versus winter logging on understory vegetation in the Chequamegon-Nicolet National Forest. Forest Ecol. Manag. 254:35-45. 


\title{
Chapter Three
}

\author{
Suitability of Cardamine concatenata (Michx.) Sw. as a \\ Management Indicator Species on the Ottawa National Forest
}

\begin{abstract}
The cutleaf toothwort (Cardamine concatenata) is one of four Management Indicator Species monitored on the Ottawa National Forest. It is a perennial spring ephemeral used to indicate effects of forest management of northern hardwoods on site conditions. Surveys were conducted in 131 managed and unmanaged stands. Stands were monitored for abundance of $C$. concatenata as well as abundance of three other spring ephemerals (Cardamine diphylla, Claytonia caroliniana, and Allium tricoccum). Additional site characteristics that could affect toothwort abundance were monitored, including micro-topography, ground flora, earthworm disturbance, and deer browse. Analysis assessed both the impact of management on site conditions and the suitability of using $C$. concatenata as a Management Indicator Species. Results showed no significant relationship between hardwood-management and $C$. concatenata abundance. While $C$. concatenata was representative of the other three spring ephemerals monitored, its widespread absence across the Ottawa National Forest raises questions as to its suitability as a Management Indicator Species.
\end{abstract}

Keywords: Cardamine concatenata, Dentaria laciniata, Management Indicator Species, forest management 


\section{Introduction}

Indicator species are used for efficient monitoring of the status of flora, fauna and environmental conditions in a particular area, but their use in ecosystem and biodiversity management has been widely critiqued (Niemi et al. 1997; Caro and O’Doherty 1999; Landres et al. 1988; Lindenmeyer et al. 2000; Carignan and Villard 2002; Nylen 2011). The USDA Forest Service uses Management Indicator Species (MIS) in the monitoring of plant and animal populations to indicate population status and environmental conditions. The cutleaf toothwort, currently referred to as Cardamine concatenata (Michx.) Sw. but previously identified as Dentaria laciniata Muhl. ex Willd., is used as an indicator of impacts of northern hardwood forest management on site conditions on the Ottawa National Forest (ONF). As a spring ephemeral species representative of that guild, C. concatenata was selected as an indicator because of its habitat specificity to mesic hardwood stands, its sensitivity to disturbance, its slow dispersal rate, and its presumed non-palatability to deer. In this paper, results from monitoring data of $C$. concatenata and three other spring ephemerals, in stands with different harvest histories are analyzed to assess both the impact of hardwoods management on site conditions and the suitability of $C$. concatenata as a management indicator.

\section{Indicator Species in Forest Management}

Indicator species are often used for three general purposes: as indicators of biodiversity, of populations, and of ecosystem health. Biodiversity indicators are groups of species whose richness in a given geographic area is meant to indicate richness in other groups of species in that area (Caro and O’Doherty 1999). Population indicator 
species, often termed surrogate species (Wiens 2008), are used as proxies for other species believed to have similar habitat preferences or guild membership. Ecosystem health indicators give insight into the conditions of the resources upon which species depend (Landres et al. 1988; Caro and O’Doherty 1999). Despite the skepticism around the use of individual or groups of species as proxies for biodiversity or populations of related species (Landres et al. 1988; Niemi et al. 1997), it is recognized in the literature that, when the complexity of factors affecting an indicator species are well understood, ecosystem health indicators can be useful for efficient monitoring of management impacts on plant and animal diversity (Caro and O'Doherty 1999, Carignan and Villard 2002).

Because no two species are identical in their habitat needs and responses to stress, population indicator species are considered to be unreliable indicators of population trends in related vertebrate species (Landres et al. 1988; Niemi et al. 1997), and within guilds (Verner 1984; Block et al. 1987). The use of guilds, which are believed "to exploit the same class of environmental resources in a similar way" (Root 1967), is disputed given that the actual resources used and the methods species employ to obtain them can vary considerably (Root 1967; Verner 1984; Block et al. 1987). Where species are dependent upon the same habitat, competition for limited resources may actually result in an inverse relationship between two populations (Steele 1984; Carignan and Villard 2002).

Biodiversity indicators have been promoted for their utility in identifying biodiversity hotspots and in targeting specific geographic areas for conservation, yet their validity is disputed in the scientific literature. In some larger geographic areas, species 
richness within taxonomic groups has been successfully correlated to richness in other groups (Pearson and Cassola 1992; Caro and O’Doherty 1999). In other areas, however, little correlation has been found between species richness in one taxon to richness in another (Prendergast et al. 1993; Prendergast and Eversham 1997; Pärt and Söderström 1999; Carignan and Villard 2002). Species richness as a proxy for biodiversity has been criticized on the grounds that high species diversity is not necessarily correlated to high habitat quality or the presence of rare species (Prendergast et al. 1993; Dufrêne and Legendre 1997; Carignan and Villard 2002). An increase in herbaceous species richness following disturbance is often attributed to a change in species composition in which generalist, shade intolerant, or invasive plants colonize canopy gaps and sensitive or rare species are removed (Meier et al. 1995; Zenner and Berger 2008). As the size of the geographic area decreases, species richness as a proxy for biodiversity becomes less capable of accurately identifying areas where diversity is high and rare or sensitive species are present (Prendergast and Eversham 1997).

Ecosystem health indicators, including individual species and groups of species of both plants and animals, are believed to provide insights into environmental conditions. Given their known site or resource requirements, habitat conditions can be inferred using monitoring of indicator species populations. The presence or abundance of plant species on a site is informative of that species' required moisture, soil, temperature, and light conditions at that site. Just as groups of species, termed "ecological species groups" (Kashian et al. 2003) or "species assemblages" (Dufrêne and Legendre 1997), are used in site classification systems (Barnes et al. 1982), they are also used to indicate a number of factors relevant to the conditions at a site that no one species can elucidate alone. 
There are, however, various factors unrelated to habitat quality that can affect the populations of indicator species without necessarily affecting related species. Parasites, diseases, predation, cyclical population growth patterns, and competition may affect vertebrates (Steele 1984; Landres et al. 1988; Carignan and Villard 2002), while abundance of herbaceous species is influenced by browse, dispersal rates, and history of disturbance (Kashian et al. 2003). Given the diversity of factors that affect populations, it can be difficult to assess the impact of each on an indicator species and to correlate observations of indicator species populations to environmental conditions (Landres et al. 1988).

Ecosystem health indicators are used to provide insights into conditions at both small and large scales (i.e. at the stand and the landscape level). In assessing changes across a landscape, it is recommended that monitoring programs include a variety of species that operate at different scales (small, large, specialist, generalist) so that shortand long-term, as well as specific and broad habitat changes can be observed (Landres et al. 1988). Considering that efficiency is a principal motivation for relying on indicator species, species selection should take into account their ease of monitoring. Species should be easily identifiable, their populations should be accessible for survey, and their population levels should be high enough that absence is not a problem (Caro and O’Doherty 1999). The specific resource dependencies and the external factors that can affect changes in the population of selected species should be well-understood (Pearson and Cassola 1992; Caro and O'Doherty 1999). 
Herbaceous Species as Ecosystem Health Indicators of Forest Management

Natural resources managers use ecosystem health indicators to monitor the impacts of active management on site conditions at the stand and landscape levels. Disturbance resulting from timber harvesting can cause a number of changes to soil productivity, moisture, light regimes, and temperature on the forest floor. When harvesting activities are not carried out over snow or frozen ground, skidder traffic can cause soil compaction and removal of the litter layer, resulting in lower infiltration rates and increased erosion (Grigal 2000; Brais 2001; Zenner and Berger 2008). Opening of the canopy allows for increased light penetration to the forest floor, causing an increase in temperature (Brooks and Kyker-Snowman 2008) and cover of herbaceous species (Metzger and Shultz 1984; Scheller and Mladenoff 2002). While changes in soil moisture vary depending on harvest intensity and soil disturbance, soil moisture is generally believed to increase following tree removal due to lower transpiration rates (Bormann 1979; Grigal 2000; Stoffel et al. 2010).

The degree of disturbance and the rate of recovery of site conditions and stand composition in hardwoods are affected by the intensity and frequency of management (Metzger and Shultz 1984; Fredericksen et al. 1998; Zenner et. al. 2006). Group selection and clear-cutting cause significant changes immediately following harvest, including a shift in species composition from more sensitive herbs to ruderals (Meier et al. 1995; Zenner and Berger 2008). Intensively harvested northern hardwood sites are slow to recover to secondary growth conditions. The impact of single-tree selection and thinning is less severe because uneven-aged management regimes more closely mimic natural stand succession (Barnes et al. 1998; Zenner et al. 2006). Under uneven-aged 
management, initial recovery may begin within five years (McComb and Noble 1982; Metzger and Shultz 1984; Reader and Bricker 1992). As succession progresses and light penetration to the forest floor decreases over time, the site gradually recovers to resemble pre-harvest conditions (Barnes et al. 1998). As time from harvest increases, species composition and abundance will be expected to change and reflect the stage of stand succession.

The frequency at which stand disturbance occurs under natural succession is distinct from when logging is conducted. Cutting cycles, typically 10 to 20 years in northern hardwoods in the upper Great Lakes area (Martin and Lorimer 1996), impose changes at a much faster rate than natural processes (Barnes et al. 1998). With increased frequency of harvest, understory species, especially those characteristic of latesuccessional forests, are less capable of recolonizing a site (Brewer 1980; Duffy and Meier 1992; Tonteri 1993). In the natural rate of succession, stands may take more than one hundred years to recover, with changes to understory species composition continuing as overstory structure and composition develop (Brewer 1980; Duffy and Meier 1992; Tonteri 1993). Given the length of time required for recovery in some cases, external factors such as climatic changes, excessive deer herbivory, and forest health issues, may prevent stands from ever fully returning to pre-harvest conditions and species composition (Brewer 1980; Duffy and Meier 1992).

When using herbaceous plants as indicators of management impacts on site conditions, it is recommended to use species that are sensitive to change and fairly specialized in their habitat type and site conditions requirements (Caro and O'Doherty 1999). Within each habitat type (dry conifer, mesic hardwood, swamps, etc.), site 
characteristics such as soil conditions, light availability, and topography vary at the stand level. Plants that favor specific conditions, such as shade-intolerant species that colonize canopy gaps, are good indicators of those conditions and for inferring stage of stand succession (McLachlan and Bazely 2001). Species that are sensitive to change are used to correlate abundance of the indicator species to the degree of disturbance at a site (Graul and Miller 1984). Species that are so sensitive or specialized that they are rare are not good indicators because their low populations are difficult to find and monitor and are incapable of providing useful monitoring data (Landres et al. 1988).

The ability to directly correlate a specific site factor to abundance of an indicator species is essential to the utility of indicator species (Pearson and Cassola 1992). Susceptibility to external factors, such as deer browse, distorts this ability and weakens the utility of an indicator species (Landres et al. 1988). Species with slow dispersal rates, such as ballistic or ant dispersal, have been proposed as good indicators of stand recovery because they are slow to recolonize a site after disturbance (Lambeck 1997). Their limited dispersal ability is an external factor that can prove misleading, however, if the species' ability to recolonize is limited, not by recovery of site conditions, but by an absence of remnant populations on sites within the same geographic area (Dzwonko and Gawrónski 1994). On sites where soil, moisture, and light conditions have recovered to a suitable condition, species composition recovery may still be limited by the slow dispersal rates of certain species (Racke 2010). The use of such herbaceous plants as health indicators can confound analysis of management impacts because even when site conditions have recovered, ground flora may never fully resemble pre-harvest species composition. 


\section{The Forest Service MIS System}

The USDA Forest Service uses MIS to monitor forest management and other impacts on biodiversity and ecosystem health. In order to comply with the 1976 National Forest Management Act (NFMA) "biodiversity mandate," as it is commonly referred to, the 1982 NFMA Planning Rule (36 C.F.R. § 219.19) created the MIS system. The "biodiversity mandate" requires that all National Forests "provide for diversity of plant and animal communities based on the suitability and capability of the specific land area in order to meet overall multiple-use objectives" (16 U.S.C. § 1600(g)(3)(B)). Challenged with managing for multiple uses, including plant and animal diversity, indicator species are relied upon where monitoring of all plant and animal species would be prohibitively costly.

The MIS system has been criticized for being ineffective in fulfilling the biodiversity mandate. The use of population indicators has been widely criticized and is no longer grounded in the scientific literature (Owen 2010; Nylen 2011; 36 C.F.R. § 219 2012). The lack of clear guidelines as to how to design a valid indicator species monitoring program has resulted in some cases in the selection of species that have populations that are too small to provide for sufficient monitoring and selection of inappropriate species (such as popular game) that do not provide useful information for monitoring biodiversity (Nylen 2011). The Forest Service is challenged with providing standardized protocols that offer sufficient guidance, but that are sufficiently flexible to be adapted to the diverse conditions at each national forest (Nylen 2011).

Critics of the MIS system suggest that monitoring programs should be utilized as one aspect of an adaptive process that allows for ever-growing bodies of knowledge that 
the Forest Service can draw upon to improve the management of natural resources (Stanford and Poole 1996; Lindenmeyer 2000; Nylen 2011). Within an adaptive management framework, monitoring programs are designed in conjunction with management activities. After execution of management activities, monitoring is performed. Monitoring data are then analyzed, from which statistically relevant results may be derived to inform future land use and to refine monitoring (Everett et al. 1993; Stankey et al. 2005). In this last phase, partnerships with researchers at universities and within the Forest Service research division can serve to complement land managers who may lack the time, tools, expertise, or perspective to assess their management actions (Nylen 2011). Adaptive management systems are ultimately important for reducing uncertainty around the impacts of management on environmental conditions, to benefit land managers both within and outside of the Forest Service (Williams et al. 2009).

Since 2000, the Forest Service has proposed a number of changes to the original 1982 NWFA Planning Rule. The drafting processes and subsequent rules have taken criticisms into account. The newest planning rule, effective as of May 2012 (36 C.F.R. § 219), acknowledges that the use of population indicator species is no longer supported in science. The new rule is consistent with previously proposed planning rules that moved away from "management indicator species" (population indicators) to what are termed "focal species," which are meant to serve as indicators of "ecological conditions" (36 C.F.R. $\S 219$ 2000). This shift has been accompanied by an attempt to incorporate an adaptive management approach in which the monitoring of a carefully selected group of focal species is used to better understand management impacts on environmental conditions (Chase and Geupel 2005; Owen 2010). 
C. concatenata as an indicator of northern hardwood forest management impacts

On the ONF, C. concatenata is one of four species or species suites monitored under the MIS system since 2006 when the Forest Plan was revised. C. concatenata is a low-growing native spring ephemeral in the mustard family (Figure 3.1). It is found in the understory of northern hardwood stands on nutrient-rich sites. C. concatenata is used to monitor impacts of timber harvesting of northern hardwood stands on site conditions. The analysis in this paper of both management impacts and the usefulness of $C$. concatenata as an indicator species is an effort to incorporate adaptive management strategies into the MIS system on the ONF.

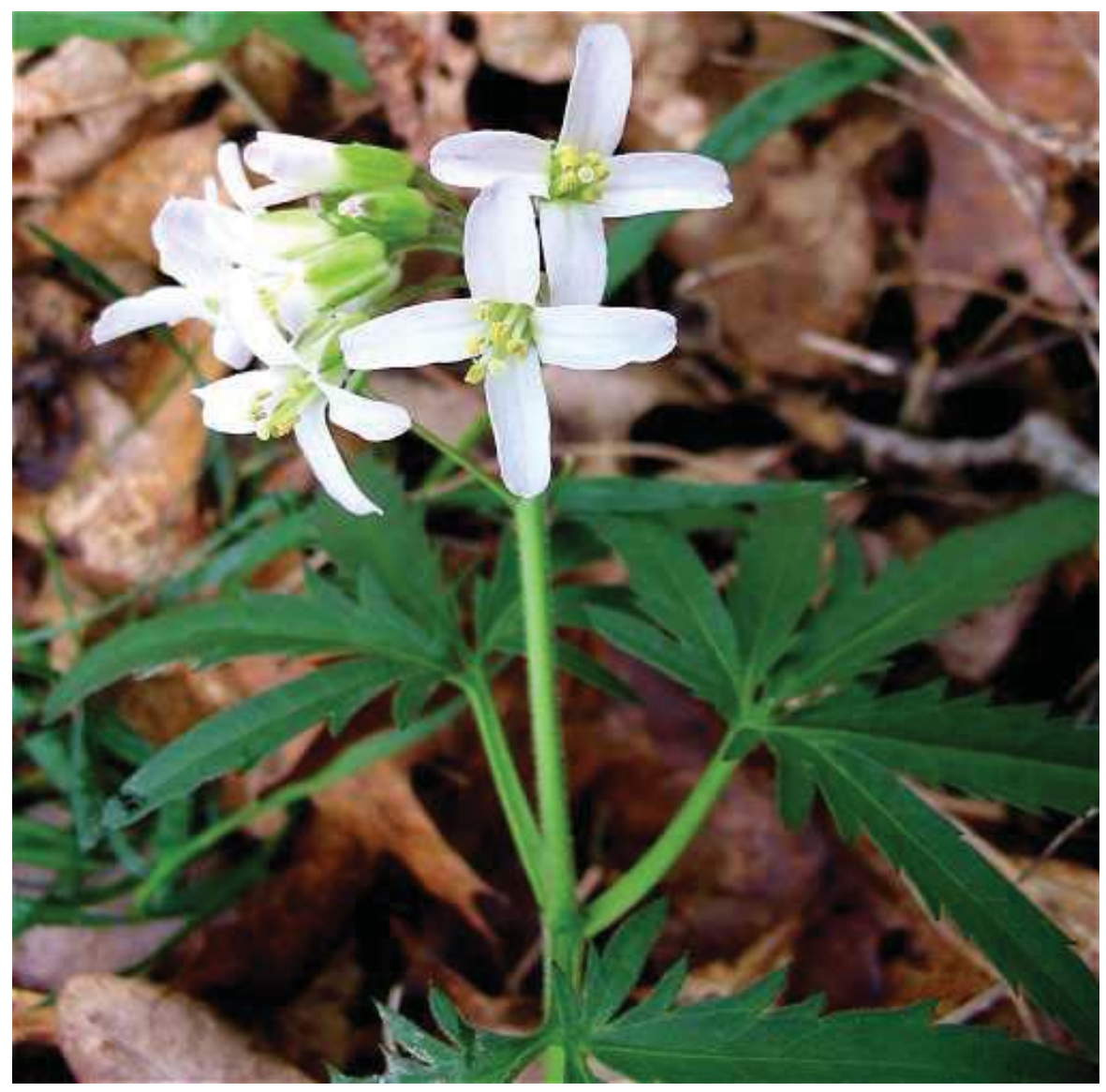

Figure 3.1. Flowering C. concatenata (Steele). 
Spring ephemerals are regarded as good indicators of site conditions because they require moist conditions, nutrient-rich soil, and an absence of competition from other ground flora in early spring (Eickmeier and Shussler 1993; McLachlan and Bazely 2001). Since their life cycle begins before leaf emergence, their presence is influenced, not so much by canopy cover, as by soil characteristics, moisture, and temperature on the forest floor (Bratton 1994). Disturbance can result in their absence from a site either as the direct result of harvest or indirectly due to changes in site conditions associated with hardwood management activities (Dzwonko 1993; Meier et al. 1995). Spring ephemerals typically have limited dispersal ability, through ant or ballistic methods, meaning that once absent from a site, they are slow to recolonize (Dzwonko and Loster 1992). Their absence from a site following harvest is considered an indication that management activities resulted in changes on the forest floor, and their recolonization may be an indicator of site recovery if a seed source is available.

Of the spring ephemerals found in northern hardwood stands on the ONF, $C$. concatenata was chosen for monitoring because of its sensitivity to disturbance, ease of monitoring, and its association with the hardwood cover type. Since deer are presumed to be less likely to browse on plants in the mustard family, this external factor might not distort monitoring data. C. concatenata was chosen over the two-leaf toothwort (Cardamine diphylla), another mustard, because it is easier to distinguish and it is also a host plant for the West Virginia White butterfly (Pieris virginiensis), a species on the Regional Forester's Sensitive Species list for the ONF. The leaves of C. concatenata turn yellow during senescence in late May or early June, facilitating spotting of plants during field surveys (Figure 3.2). Vegetative reproduction and ballistic dispersal limit its range 
and ability to recolonize sites after disturbance. C. concatenata is usually found in northern hardwood stands, focusing insights from monitoring to conditions in the northern hardwood habitat type across the ONF.

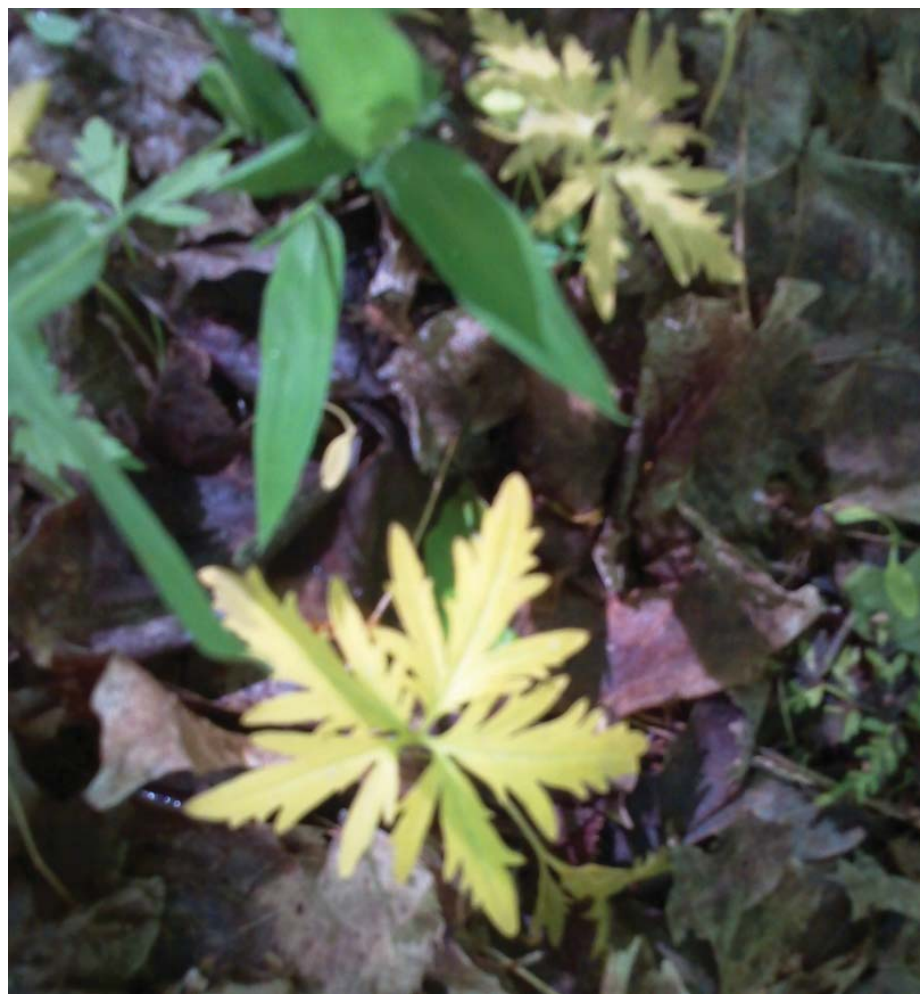

Figure 3.2. C. concatenata during senescence taken while surveying on the ONF (Fox).

\section{Methods}

Based on the known habitat preferences of $C$. concatenata, the Ottawa National Forest Geographic Information System (GIS) was used to identify northern hardwood stands on nutrient-rich sites. Acer-Viola-Osmorhiza (AVO) and Acer-OsmorhizaCaulophyllum (AOC) ecological landscape phases were chosen because they designate rich, moist soils (Coffman et al. 1984). Stands identified as northern hardwoods had 
sugar and red maple, hemlock, yellow birch, and basswood as dominant tree species.

Sites fulfilling both of these characteristics were considered to be suitable habitat for $C$.

concatenata. Individual stand management history was identified based on ONF records.

Forest management activities included, generally, selection harvests, stand improvements, and commercial thinning. Three-hundred and twenty-nine non-treated stands totaling 5,668 acres and 165 treated stands totaling 4,636 acres were identified as potential monitoring sites. Treated sites are those that were harvested since the widespread logging that occurred around the turn of the $20^{\text {th }}$ century. For each year of

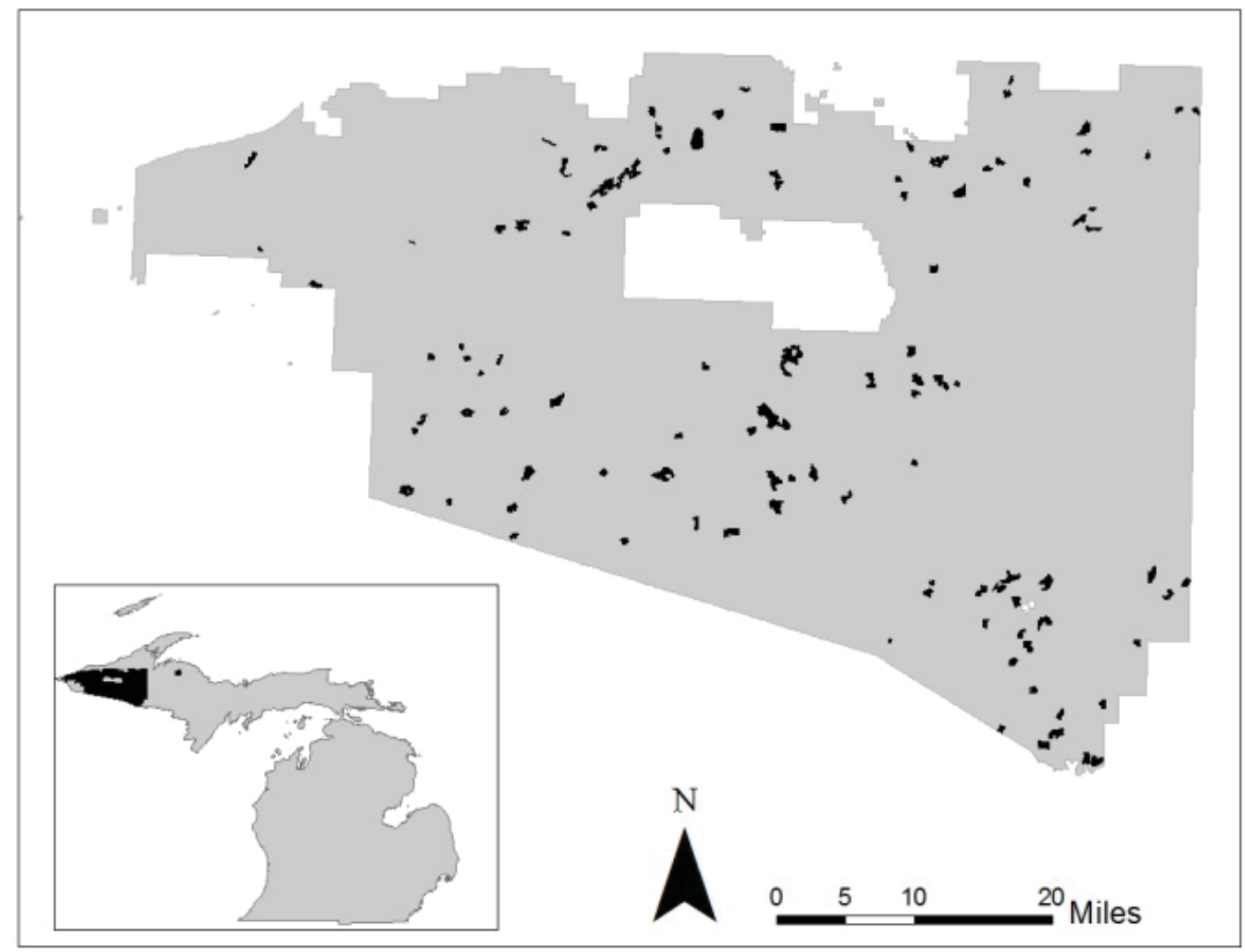

Figure 3.3. Location of monitored stands across the Ottawa National Forest in Michigan's Upper Peninsula (spatial data from USDA Ottawa National Forest). 
monitoring, a set of treated and non-treated stands that were larger than 35 acres, within easy road access, and not adjacent to previously monitored or selected stands, were chosen. Due to soil and moisture conditions on the ONF, northern hardwoods are more prevalent on the south and west portions of the Forest, hence fewer stands were selected for monitoring on the east and north portions (Figure 3.3).

Starting in 2006, sampling was conducted every year in late May or early June, due to the plant's phenology. The number of stands monitored each year varied depending on staff workloads within the short window of opportunity for monitoring during plant senescence. In each stand, a meander survey was conducted, lasting about one hour (Goff et al. 1982). Abundance, on a scale from 0 (none) to 6 (extensive) and pattern of occurrence of $C$. concatenata were recorded based on observations in the whole stand. On a scale of 0 (none) to 4 (abundant), abundance of C. diphylla, Claytonia caroliniana (spring beauty), and Allium tricoccum (wild leek) were also recorded. On a scale of 1 (scarce) to 4 (abundant), coarse woody debris, micro-topography, weedy ground flora, and sugar maple regeneration were noted. Dominant weedy ground flora species were identified and recorded. Earthworm infestation level and deer browse on woody species in the stand were each rated as high, medium, or low.

Data collected through 2011 were analyzed in SAS software (SAS Institute Inc., Cary N.C.) using the PROC FREQ and PROC GLM procedures. Because values in some abundance categories were too low to be analyzed using a chi-square test, a Fisher's exact test was used to analyze abundance data of the spring ephemeral plants to other categorical data. In cases where values in each category analyzed were too low to even use a Fisher's 
exact test, abundance was generalized to "present" and "absent". Results of all tests were declared significant at $\mathrm{p}<0.10$.

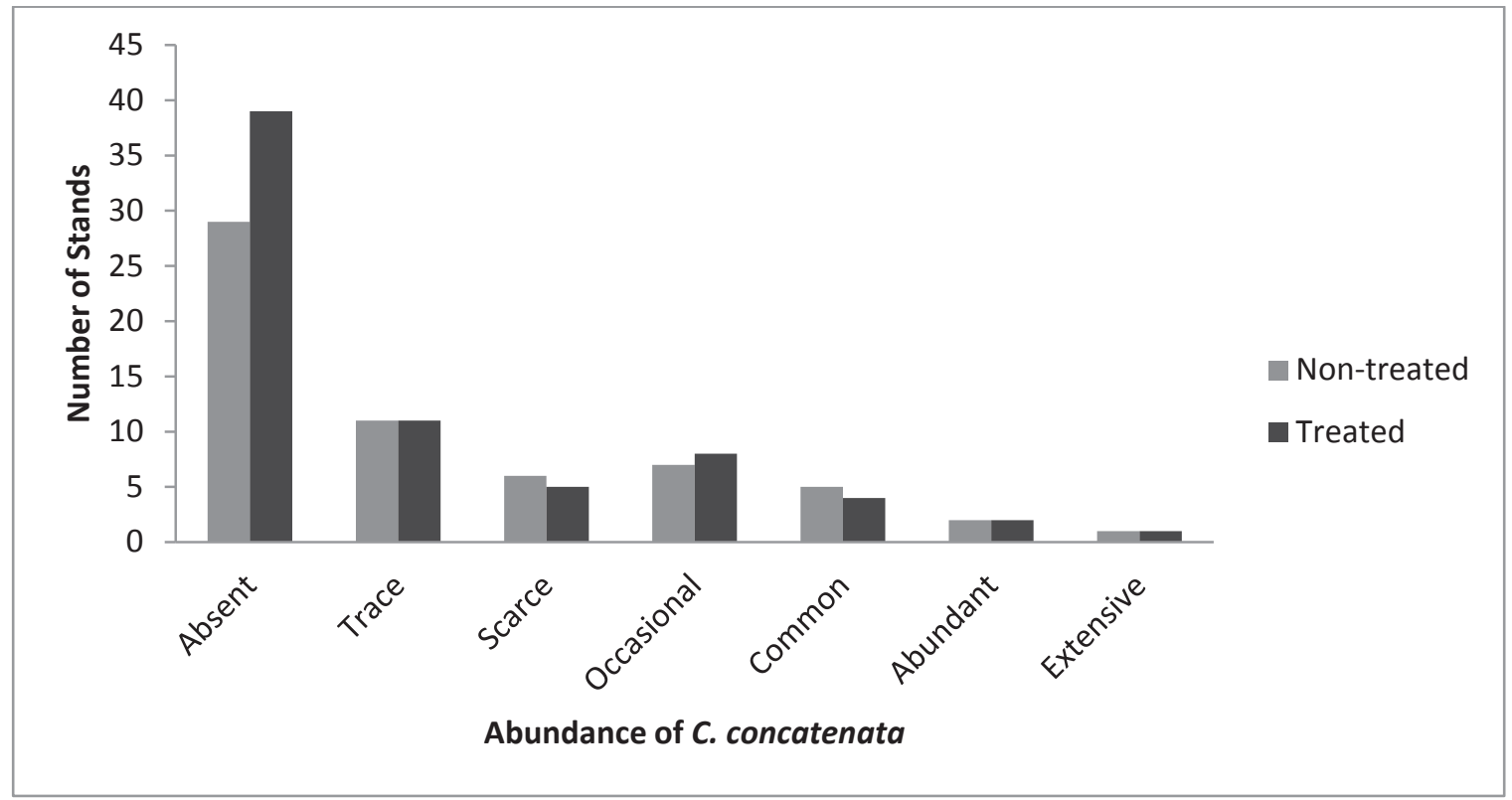

Figure 3.4. Abundance of $C$. concatenata in treated and non-treated stands. $n=131$.

A Fisher's exact test was used in the following procedures. Differences in abundance in treated versus non-treated stands were tested on all four spring ephemeral species.

Difference in abundance of $C$. concatenata by harvest type was tested for each activity type. Activity types included single-tree selection cutting, overstory removal cutting, improvement cutting, commercial thinning, pre-commercial thinning, and initiation of natural regeneration. Presence versus absence of $C$. concatenata was tested against presence versus absence of C. diphylla, C. caroliniana, and A. tricoccum. Abundance of all four spring ephemerals were tested against degree of deer browse. C. concatenata abundance, extent of earthworm effects, and $C$. concatenata presence and absence values were tested against abundance of weedy ground flora and micro-topography. 
A Tukey's Studentized Range test was used to determine if number of years since management and if time spent conducting surveys were factors affecting $C$. concatenata abundance. Number of years since management ranged from 5 to $33($ mean $=20.7)$. Time spent surveying ranged from half an hour to one and a half hours.

A spatial autocorrelation was used to assess the pattern of C. concatenata abundance in each stand monitored across the ONF. ArcGIS 10.1 (ESRI, 2011) software was used. C. concatenata abundance was set as the input field, using inverse distance as the conceptualization of spatial relationships parameter and Euclidean distance as the distance method. The data were not standardized.

\section{Results}

In the following analysis, $C$. concatenata abundance was correlated with harvest, based on the assumption that $C$. concatenata is a suitable indicator. This assumption is then tested by analyzing the ability of $C$. concatenata to indicate site conditions. Suitability as an indicator species is determined by the ability, first, of $C$. concatenata to represent the other spring ephemeral species and, second, to directly correlate abundance to harvest impacts, controlling for external factors that may also affect population abundance. Sound interpretation of monitoring results requires consideration of factors independent of recent harvest activity.

\section{Effects of harvest on site conditions}

The Fisher's exact test showed no significant difference in C. concatenata abundance between treated and non-treated stands $(\mathrm{p}=0.98)$. The same test was used to 
determine if the other spring ephemerals that were monitored showed a difference under treated or non-treated conditions. There was no significant difference in C. diphylla $(\mathrm{p}=$ $0.70)$, C. caroliniana $(\mathrm{p}=0.72)$, or A. tricoccum $(\mathrm{p}=0.23)$ abundance between treated and non-treated stands. There was also no difference in $C$. concatenata abundance in relation to time in years since harvest $(\mathrm{p}=0.66)$. The results indicate that forest management was not a factor affecting abundance of spring ephemeral species.

The harvest activities would have produced disturbances that varied in degree and character. The Fisher's exact test showed no significant difference in abundance of $C$. concatenata under six out of the seven activity types, with the exception of improvement cutting (Table 3.1). Once the 66 managed sites were divided by activity type, the size of individual data sets was so small in some cases that statistical tests may not be valid. The

Table 3.1. Relationship between C. concatenata and management activity type. $\mathrm{n}=66$, $\mathrm{df}=6$.

Activity Type

Single tree selection cut

Improvement cut

Commercial thin

Sanitation cut

Overstory removal cut

Initiate natural regeneration

Pre-commercial thin
Table Probability p-value

$\begin{array}{ll}>0.0001 & 0.41 \\ >0.0001 & 0.04\end{array}$

0.0012

0.64

0.1207

0.52

0.5606

1.00

0.1698

1.00

0.0092

0.38 
results indicate that intensity of disturbance was also not a factor affecting abundance of the other spring ephemeral species.

Suitability of C. concatenata as a MIS

The Fisher's exact test was used to assess if $C$. concatenata is a good representative of the other spring ephemeral species. The results showed that the relationship between abundance of $C$. concatenata and $C$. diphylla $(\mathrm{p}<0.0001), C$. caroliniana $(\mathrm{p}=0.0014)$, and A. tricoccum $(\mathrm{p}<0.0001)$ was significant. These results indicate that $C$. concatenata is representative of the other spring ephemeral species.

To assess the reliability of using $C$. concatenata as an indicator species, additional factors affecting its abundance were analyzed. C. concatenata was found to be absent from 68 out of 131 sites (Figure 3.4). The relationships of deer browse in the stand to $C$. concatenata $(\mathrm{p}=0.83)$, C. diphylla $(\mathrm{p}=0.70)$, C. caroliniana $(\mathrm{p}=0.12)$, and $A$. tricoccum $(\mathrm{p}=0.51)$ were not significant. C. concatenata abundance as related to earthworm disturbance was not significant $(\mathrm{p}=0.13)$. Abundance as related to time spent conducting surveys was also not significant $(\mathrm{p}=0.10)$. C. concatenata presence versus absence was significant as it related to micro-topography abundance $(\mathrm{p}=0.09)$ and was not significant in relation to weedy ground flora abundance (i.e. competition) $(p=0.26)$. Results from the spatial autocorrelation, used to assess the pattern of C. concatenata abundance in each stand monitored, showed a clustering pattern across the ONF ( $\mathrm{p}=$ $0.0008, z=3.368)$. The data were not standardized because of the low variance of 0.0045. The analysis shows that on a range from 0 (absent) to 6 (extensive), sites with the same abundance values are located close together on the landscape. 


\section{Discussion}

If it is assumed that $C$. concatenata is a good indicator of site conditions, then the statistical similarity of spring ephemeral abundance in the treated and non-treated stands indicates that harvest activities are not negatively affecting site conditions in northern hardwood stands on the ONF. The harvest techniques, protective design criteria, and best management practices employed by the ONF thus would not be expected to significantly alter soil conditions or herbaceous plant composition. The expected increase in soil moisture following harvest (Bormann 1979; Grigal 2000; Stoffel et al. 2010), would provide the moist conditions required by spring ephemerals. Restriction of harvesting to winter months prevents the soil compaction and organic layer disturbance that are the most detrimental to site conditions (Grigal 2000; Brais 2001; Zenner and Berger 2008). Single-tree selection and thinning, as opposed to group selection and clear-cutting, are known to more closely mimic dynamics within non-treated stands (Zenner et al. 2006).

Results showed that $C$. concatenata is representative of the other spring ephemerals but that as a group there was little distinction between the four spring ephemeral species as they related to other factors. None of the spring ephemerals appeared to be affected by harvest activities. The presumed avoidance of mustard plants by deer was not contradicted in the results, though browse was not significant in its relationship to any of the spring ephemerals. Of the mustard plants, the two-leafed toothwort had an even higher degree of absence (from 93 of 101 stands). C. concatenata therefore appears to be representative and an adequate indicator of the other three spring ephemerals. 
The ability to correlate $C$. concatenata abundance to impacts of harvest on site conditions is weakened by the low population levels of the plant across the surveyed stands. C. concatenata was identified at only 68 out of 131 sites, and on sites where it was present, abundance was low (Figure 3.4). Where present, the low population levels make it difficult to determine the degree to which forest management may be a factor affecting abundance. Its widespread absence indicates that factors independent from recent treatments are affecting $C$. concatenata abundance. Analyses of the other factors monitored in each stand, including hours spent conducting surveys, earthworm disturbance, weedy ground flora cover, and micro-topography were not useful in explaining C. concatenata population dynamics. With increased time spent conducting surveys, observers were not more likely to identify a greater abundance of $C$. concatenata plants. Neither earthworm disturbance nor weedy ground flora cover had an impact on $C$. concatenata abundance. The influence of harvest on micro-topography complicates interpretation of its relationship to C. concatenata abundance.

A plausible explanation for the widespread absence of $C$. concatenata is that as a result of its limited dispersal ability, it may still be recovering from the intensive disturbance that occurred at the turn of the $20^{\text {th }}$ century (U.S.D.A. Forest Service 2006). At that time, forests across much of the Upper Peninsula of Michigan were clearcut and often burned over for their valuable timber. In the same period, over multiple years, fire swept through many parts of the area currently within the ONF, with at least $20 \%$ burning three to four times (Karamanski 1989). Following such intensive disturbance, only isolated populations of $C$. concatenata likely survived. Stands can take over a hundred years to recover from intensive disturbance (Brewer 1980; Duffy and Meier 1992; 
Tonteri 1993), and recovery of $C$. concatenata populations would be limited by their dispersal ability. Ballistic dispersal of woodland herbaceous plants is on average only 1.5 meters per year (Cain et al. 1998). With the source for recolonizing C. concatenata plants limited to remnant populations, recovery of the plant across the approximately one million acres encompassed in the ONF may still be in progress.

The clustering of $C$. concatenata populations across the ONF indicates that population abundance is correlated to geographic position. Without survey data covering a greater portion of stands across the ONF or population data from before the acquisition of the forest, a more precise mapping of $C$. concatenata populations in relation to latesuccessional stands is not possible. The spatial autocorrelation results do illustrate that absence of $C$. concatenata from sites may be a factor of geographic position on the forest, suggesting that populations are still in the process of recolonizing areas of the ONF.

While the limited dispersal of spring ephemerals is considered to enhance their usefulness as indicator species (McLachlan and Basely 2001), it may prove misleading in cases where absence from a site is better explained by their slow rate of recolonization than site conditions. In western Kentucky, transplant of spring ephemeral species to northern hardwood sites with a history of disturbance resulted in survival and selfpropagation, indicating that absence from the site was due to dispersal limitation and not site conditions (Racke 2010). In Poland, landscape analysis of spring ephemeral population recovery determined that close proximity to undisturbed forests was a factor affecting spring ephemeral presence in secondary forests (Dzwonko and Gawrónski 1994). While it is not conclusive that the legacy of logging and fire from the turn of the 
century are still affecting $C$. concatenata populations, it is one reasonable explanation for the widespread absence of the plant across the ONF.

\section{Conclusion}

Results of this study indicate that $C$. concatenata is only partially suitable as an indicator species. It has some of the characteristics that are recommended in indicator species, and it is representative of other spring ephemerals. It is selective in its colonization of mesic hardwood sites, sensitive to disturbance, presumed to be avoided by deer, and has limited dispersal ability. Due to the external factors confounding interpretation of monitoring results, however, its abundance cannot be confidently correlated to the impact of forest management on site conditions. The widespread absence of $C$. concatenata makes it difficult to decipher whether its absence resulted from recent disturbance or from other factors. The intensive disturbance that occurred at the turn of the $20^{\text {th }}$ century may be one significant factor affecting $C$. concatenata absence. Northern hardwood stands may take many years to recover, and on intensively and repeatedly disturbed sites, species composition may forever be altered. Results of this study show that it is difficult to monitor site conditions using health indicators given the complexity of factors that can affect individual species.

\section{Literature Cited}

Barnes, B.V, K.S. Pregitzer, T.A. Spies and V.H. Spooner. 1982. Ecological forest site classification. J. Forestry 80:493-498. 
Barnes, B. V., D. R. Zak, S. R. Denton, and S. H. Spurr. 1998. Forest Ecology: Fourth Edition. New York: John Wiley \& Sons, Inc.

Block, W.M., L.A. Brennan and R.J. Gutierrez. 1987. Evaluation of guild-indicator species for use in resource management. J. Wild. Manag. 63:1162-1171.

Bormann, F. H and G. E. Likens. 1979. Pattern and Process in a Forested Ecosystem. New York: Springer-Verlag.

Brais, S. 2001. Persistence of soil compaction and effects on seedling growth in Northwestern Quebec. Soil Sci. Soc. Am. J. 65:1263-1271.

Bratton, S. P. 1994. Logging and fragmentation of broadleaved deciduous forests: Are we asking the right ecological questions? Conserv. Biol. 8:295-297.

Brewer, R. 1980. A half-century of changes in the herb layer of a climax deciduous forest in Michigan. J. Ecol. 68: 823-832.

Brooks, R. T. and T. D. Kyker-Snowman. 2008. Forest floor temperature and relative humidity following timber harvesting in southern New England, USA. Forest Ecol. Manag. 254:66-73.

Cain, M. L., H. Damman, and A. Muir. Seed dispersal and the Holocene migration of woodland herbs. Ecol. Monogr. 68:325-347.

Carignan, V. and M. Villard. 2002. Selecting indicator species to monitor ecological integrity: A review. Environ. Monit. Assess. 78:45-61.

Caro, T.M. and G. O'Doherty. 1999. On the use of surrogate species in conservation biology. Conserv. Biol. 13:805-814. 
Chase, M. K. and G. R. Geupel. 2005. The use of avian focal species for conservation planning in California. USDA Forest Service Gen. Tech. Report PSW-GTR-191: $130-142$.

Coffman, M. S., E. Alyanak, J. Kotar, and J. E. Ferris. 1984. Field Guide Habitat Classification System for Upper Peninsula of Michigan and Northeast Wisconsin. Houghton, MI: Michigan Technological University.

Diekmann, M. 2003. Species indicator values as an important tool in applied plant ecology - a review. Basic Appl. Ecol. 4:493-506.

Duffy, D. C. and A. J. Meier. 1992. Do Appalachian herbaceous understories ever recover from clearcutting? Conserv. Biol. 6:196-201.

Dufrêne, M. and P. Legendre. 1997. Species assemblages and indicator species: The need for a flexible asymmetrical approach. Ecol. Monogr. 67:345-366.

Dzwonko, Z. and S. Gawrónski. 1994. The role of woodland fragments, soil types, and dominant species in secondary succession on the western Carpathian foothills. Vegetatio 111:149-160.

Dzwonko, Z. and S. Loster. 1992. Species richness of small woodlands on the western Carpathian foothills. Vegetatio 78:15-27.

Eickmeier, W. G. and E. E. Shussler. 1993. Responses of the spring ephemeral Claytonia virginica $\mathrm{L}$. to light and nutrient manipulations and implications for the 'vernaldam' hypothesis. Bull. Torrey Bot. Club 120:157-165.

Everett, R., C. Oliver, J. Saveland, P. Hessburg, N. Diaz, and L. Irwin. 1994. Adaptive ecosystem management. In Eastside Forest Ecosystem Health Assessment-Volume II: Ecosystem management: principles and applications, ed. M.E. Jensen 
and P.S. Bourgeron, 351-364. Portland, OR: U.S. Department of Agriculture, Forest Service, Pacific Northwest Research Station.

Fredericksen, T. S., B. D. Ross, W. Hoffman, M. L. Morrison, J. Beyea, B. N. Johnson, M.B. Lester, E. Ross. 1998. Short-term understory plant community responses to timber-harvesting intensity on non-industrial private forestlands in Pennsylvania. Forest Ecol. Manag. 116:129-139.

Goff, F. G., G. A. Dawson, and J. J. Rochow. 1982. Site examination for threatened and endangered plant species. Environ. Manage. 6:307-316.

Grigal, D. F. 2000. Effects of extensive forest management on soil productivity. Forest Ecol. Manag. 138:167-185.

Graul, W. D. and G. C. Miller. 1984. Strengthening ecosystem management approaches. Wildl. Soc. Bull. 12:282-289.

Horsák, M., M. Hájek, L. Tichý, and L. Juñcková. 2007. Plant indicator values as a tool for land mollusc autecology assessment. Acta Oecologica 32:161-171.

Karamanski, T. J. 1989. Deep Woods Frontier - A History of Logging in Northern Michigan. Detroit, MI: Wayne State University Press.

Kashian, D. M., B. V. Barnes, and W.S. Walker. 2003. Ecological species groups of landform-level ecosystems dominated by jack pine in Northern Lower Michigan, USA. Plant Ecol. 166:75-91.

Lambeck, R. J. 1997. Focal species: A multi-species umbrella for nature conservation. Conserv. Biol. 11:849-856.

Landres, P.B., J. Verner and J. W. Thomas. 1988. Ecology uses of vertebrate indicator species: A critique. Conserv. Biol. 2:316-328. 
Lindenmeyer, D. B., C. R. Margules and D. B. Botkin. 2000. Indicators of biodiversity for ecologically sustainable forest management. Conserv. Biol. 14:941-950.

Martin, J. and C. Lorimer. 1996. How to manage northern hardwoods. Madison, WI: UW-Extension. http://woodlandinfo.org/publications/FEM/FEM_081.pdf (accessed June 27, 2012).

McComb, W. C. and R. E. Noble. 1982. Response of understory vegetation to improvement cutting and physiographic site in two mid-south forest stands. Castanea 47:60-77.

McLachlan, S. M. and D. R. Basely. 2001. Patterns of understory herbs and their use as indicators of deciduous forest regeneration. Conserv. Biol. 15:98-110.

Meier, A. J., S. P. Bratton and D. C. Duffy. 1995. Possible ecological mechanisms for loss of vernal herb diversity in logged eastern deciduous forests. Ecol. Appl. 5: 935-946.

Metzger, F, and J. Schultz. 1984. Understory response to 50 years of management of a northern hardwood forest in Upper Michigan. Am. Midl. Nat. 112:209-223.

National Forest Management Act. 1976. 16 U.S.C. $\S 1600(g)(3)(B)$.

National Forest System Land and Resource Management Planning rule. 2000. 36 C.F.R. $\S 219$.

National Forest System Land and Resource Management Planning rule. 2012. 36 C.F.R. $\S 219$.

Niemi, G. J., J. M. Hanowski, A. R. Lima, T. Nicholls and N. Weiland. 1997. A critical analysis of the use of indicator species in management. J. Wildl. Manag. 61:12401252. 
Nylen, N. G. 2011. To achieve biodiversity goals, the new Forest Service Planning Rule needs effective mandates for best available science and adaptive management. Ecol. L. Q. 38:241-293.

Odum, E. P. 1971. Fundamentals of Ecology. 3rd edition. Philadelphia, PA: W.B. Saunders.

Owen, W. 2010. Best practices for selecting and using Management Indicator Species. Washington, DC: USDA Forest Service, WO.

Pärt, T. and B. Söderström. 1999. Conservation value of semi-natural pastures in Sweden: Contrasting botanical and avian measures. Conserv. Biol. 13:755-765.

Pearson, D. L. and F. Cassola. 1992. World-wide species richness patterns of tiger beetles (Coleoptera: Cicindelidae): Indicator taxon for biodiversity and conservation studies. Conserv. Biol. 6:376-391.

Prendergast, J. R. and B.C. Eversham. 1997. Species richness covariance in higher taxa: empirical tests of the biodiversity indicator concept. Ecography 20:210-216.

Racke, Danielle. 2010. Reestablishing diversity in our hardwood forests: A transplant study of five spring-flowering herbs. Masters Theses \& Specialist Projects, Paper 195, http://digitalcommons.wku.edu/theses/195 (accessed June 8, 2012).

Reader, R.J. and B.D. Bricker. 1992. Value of selection cut deciduous forest for understory herb conservation: an experimental assessment. Forest Ecol. Manag. $51: 317-327$

Root, R. B. 1967. The niche exploitation pattern of the blue-gray gnatcatcher. Ecological Monographs. 37:317-350. 
Scheller, R. M., and D. J. Mladenoff. 2002. Understory species patterns and diversity in old-growth and managed northern hardwood forests. Ecol. Appl. 12:1329-1343.

Stanford, J. A. and G. C. Poole. 1996. A protocol for ecosystem management. Ecol. Appl. 6:741-744.

Stankey, G. H., R. N. Clark, and B. T. Bormann. 2005. Adaptive Management of Natural Resources: Theory, Concepts, and Management Institutions. Gen. Tech. Rep. PNW-GTR-654. Portland, OR: U.S. Department of Agriculture, Forest Service, Pacific Northwest Research Station.

Steele, B. B., R. L. Bayn, Jr. and C. V. Grant. Environmental monitoring using populations of birds and small mammals: Analyses of sampling effort. Biol. Cons. 30:157-172.

Steele, K. University of Wisconsin Stevens-Point: Robert W. Freckmann Herbarium, http://wisplants.uwsp.edu/scripts/detail.asp?SpCode=CARCON (accessed July 12, 2012).

Stoffel, J. L, S.T. Gower, J. A. Forrester, and D. J. Mladenoff. 2010. Effects of winter selection tree harvest on soil microclimate and surface $\mathrm{CO}_{2}$. Forest Ecol. Manag. $259: 257-265$.

Tonteri, Tiina. 1993. Species richness of boreal understorey forest vegetation in relation to site type and successional factors. Ann. Zool. Fennici 31:53-60.

U.S. Department of Agriculture, Forest Service. 2006. Ottawa National Forest Final Environmental Impact Statement, Forest Plan. Ironwood, MI: Ottawa National Forest. 3-124. 
Verner, J. 1984. The guild concept applied to management of bird populations. J. Env. Manag. 8:1-14.

Wiens, J. A., G. D. Hayward, R. S. Holthausen, and M. J. Wisdom. 2008. Using surrogate species and groups for conservation planning and management. BioScience 58:241-252.

Williams, B. K., R. C. Szaro, and C. D. Shapiro. 2009. Adaptive Management: The U.S. Department of the Interior Technical Guide. Washington, DC: Adaptive Management Working Group, U.S. Department of the Interior.

Zalený, D. and A. P. Schaffers. 2012. Too good to be true: pitfalls of using mean Ellenberg indicator values in vegetation analyses. Journal of Vegetation Science 23:419-431.

Zenner, E. K. and A. L. Berger. 2008. Influence of skidder traffic and canopy removal intensities on the ground flora in a clearcut-with-reserves northern hardwood stand in Minnesota, USA. Forest Ecol. Manag. 256:1785-1794.

Zenner, E. K., J. M. Kabrick, R. G. Jensen, J. E. Peck, and J. K. Grabner. 2006. Responses of ground flora to a gradient of harvest intensity in the Missouri Ozarks. Forest Ecol. Manag. 222:326-334 


\section{Chapter Four}

\section{Conclusion}

In this study, the short- and long-term impacts of disturbance on understory species were observed on the stand level and across the Ottawa National Forest (ONF), respectively. The impact of disturbance was distinct in its effect on the two species studied, Carex assiniboinensis and Cardamine concatenata. The results in both cases illuminated the numerous factors that affect a plant's response to disturbance, including the intensity of management, the biology of the plant, and various external factors. Analysis of study results provided insights into the impacts of forest management on understory species on the ONF.

In the first case in which a population of Carex assiniboinensis was monitored for changes following selection logging, management was shown to positively affect sedge presence. There was no immediate significant impact on the sedge in the season following harvest, and mean sedge presence increased in the four subsequent years. The sedge appeared to respond favorably to the increased availability of light that resulted from canopy gaps following harvest. The results indicate that, in the first five years following harvest, selection cutting in hardwood stands can have a positive impact on populations of C. assiniboinensis.

In the second case, general trends of forest management impacts on site conditions were monitored by surveying spring ephemeral plant abundance and site characteristics. Surveys were conducted between 5 and 33 years after harvest (mean $=$ 20.7). Due to its absence from half of the monitored stands, the impact of recent management on C. concatenata is unclear. Analysis showed that management was not a 
significant factor affecting C. concatenata abundance, and no other factor in the data proved capable of adequately explaining patterns of $C$. concatenata abundance across the ONF. Spatial clustering of stands with the same $C$. concatenata abundance values indicated that its limited dispersal ability may be affecting its recovery from disturbance that occurred almost 100 years ago. At the turn of the twentieth century, logging and fire in the area now within the ONF likely resulted in the fragmentation of populations of sensitive understory species, and species with limited dispersal ability may still be recovering today.

In all monitored stands, the intensity of management was low. Selection cutting was used at the C. assiniboinensis site, and in all stands monitored within the Management Indicator Species (MIS) program, thinning and single-tree selection harvests were the only management techniques used. In managed stands, harvest occurred during winter months only, and slash was removed from the C. assiniboinensis site so as not to impede plant growth. Despite the low intensity of recent management on the ONF, results of the MIS monitoring indicate that the high intensity disturbance that occurred before the establishment of the national forest may still be affecting species composition in stands across the forest.

The impact of disturbance on understory species is also highly dependent on the biology of each species. Each plant is unique in its site preferences, reproduction, dispersal, and sensitivity to change. C. assiniboinensis was found to prefer the higher light environment promoted by post-disturbance conditions. C. concatenata is known for being selective in its colonization of mesic hardwood stands, for being sensitive to disturbance, and for its slow dispersal that inhibits its ability to recolonize a site 
following disturbance. Due to these characteristics, $C$. concatenata may take many years to recolonize a site after disturbance.

The two studies in this report provided insights for management and monitoring of its impacts on the ONF. In both cases, the low intensity harvest methods used do not appear to have negatively impacted understory species. Given the observed positive response of the sedge in this study, the new insights for management of $C$.

assiniboinensis could allow for more flexibility in designing harvest plans where $C$. assiniboinensis is present. In assessing the suitability of $C$. concatenata as a Management Indicator Species, a direct correlation of disturbance to plant abundance could not be identified. Given the various factors that affect the abundance of a plant in a given stand and the recovery of site conditions following management, it is difficult to monitor site conditions using an individual indicator species. The specific and broad insights derived from this study contribute to the body of knowledge that can be utilized by Forest Service staff in managing for biodiversity on the ONF. 


\section{Appendix A}

\section{Permissions}

For Figures 2.1 and 3.1, the University of Wisconsin-Stevens Point Robert W. Freckman Herbarium gives the following permission for use of photos from their website (http://wisplants.uwsp.edu/photographers.html):

"Use and reproduction of these photographs are authorized for educational or other noncommercial purposes without prior permission but acknowledgement must be given to both the University of WisconsinStevens Point and the photographer." 


\section{For Figure 2.2, the follow permission was received from Ian Shackleford:}

Trull, Susan -FS $<$ strull@fs.fed.us $>$

Tue, Jul 17, 2012 at 5:30 PM

To: "Shackleford, Ian K -FS" <ishackleford@fs.fed.us>

Cc: "fox.peggy@gmail.com" <fox.peggy@gmail.com>

Ian,

Will you allow Peggy to use a sedge photo you took some years back? Thanks.

Sue Trull, Botanist

Ottawa National Forest

E6248 US Hwy. 2

Ironwood, MI 49938

(906)932-1330 ext. 312

strull@fs.fed.us

Shackleford, Ian K -FS <ishackleford@fs.fed.us>

Wed, Jul 18, 2012 at 11:29 AM

To: "Trull, Susan-FS" <strull@fs.fed.us $>$

Cc: "fox.peggy@gmail.com" < fox.peggy@gmail.com>

Sure! Please use the photo. You don't need to cite me. You could cite the US Forest Service if you like.

Ian

Ian Shackleford, Botanist

US Forest Service, Ottawa National Forest

E6248 US 2, Ironwood, MI 49938

(906)932-1330 x331, cell (906) 285-4329

ishackleford@fs.fed.us 